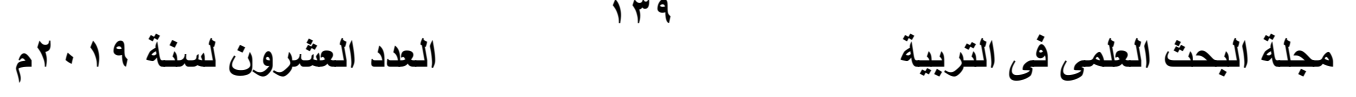

أثر استخدام نموذج أبعاد التعلم في تنمية بعض العادات العقلية لاى طلاب المرحلة الثانوية في مادة الفقه

$$
\text { طارق جبران موسى القحطاني }
$$


إن ضعف الطلاب في مستوى مهار ات التفكير في منهج الفقه ربما يرجع إلى عدة أسباب

الملخص:

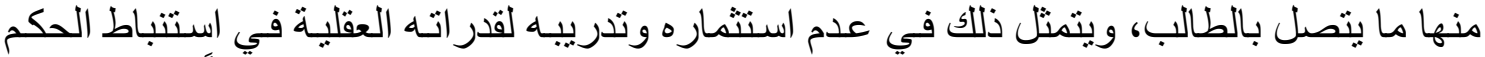

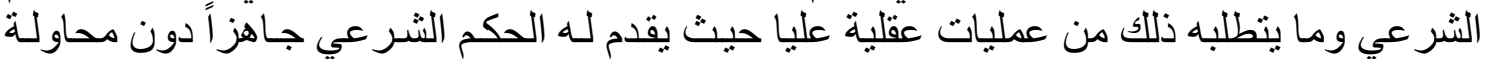
استنباطه بنفسه.

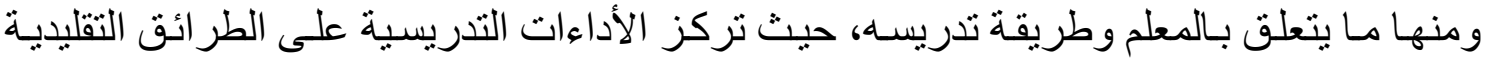

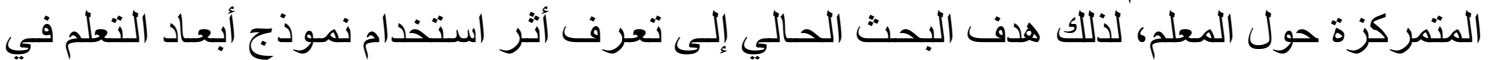
تدريس الفقه للمرحلة الثانوية في تتمية بعض العادات العقلية ولتحقيق أهداف البحث استخدم الباحث

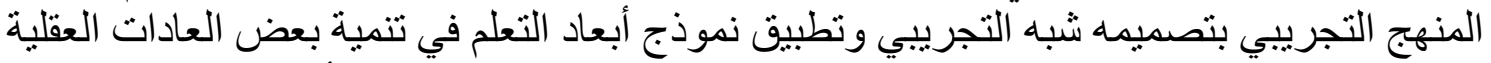

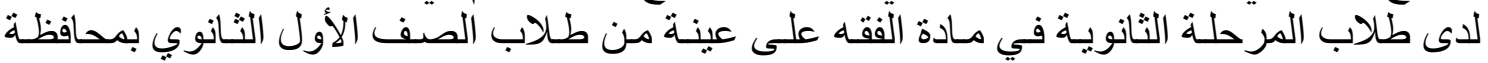

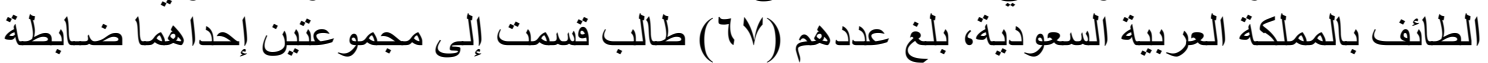
و الأخرى تجريبية.

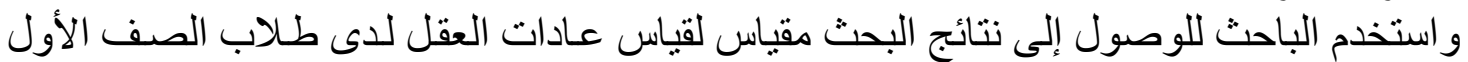

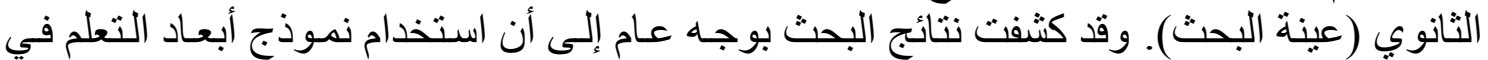

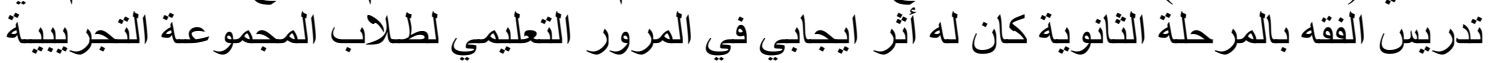

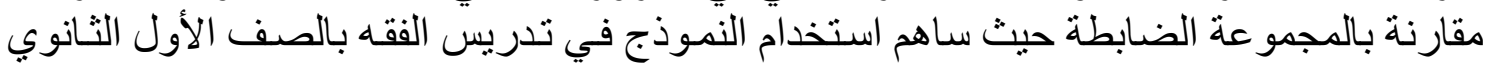

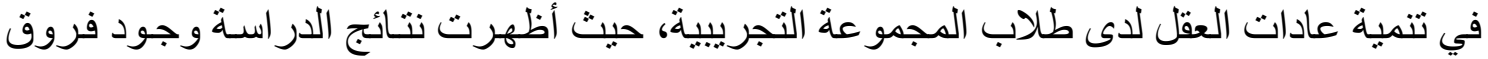

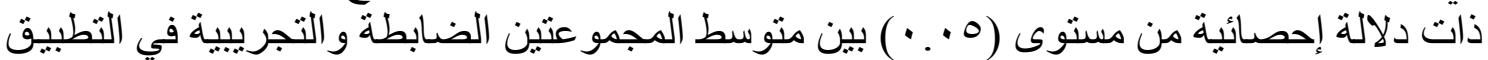

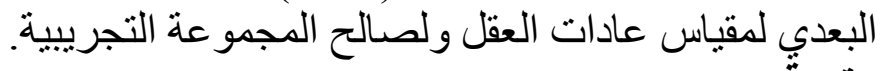
مقدمة:

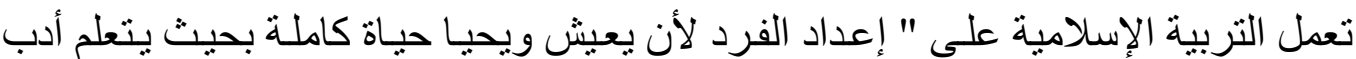

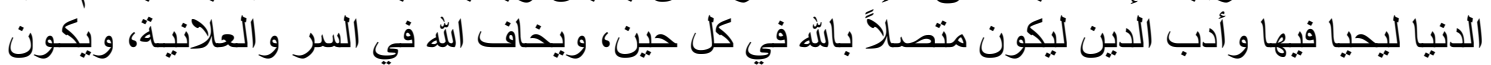

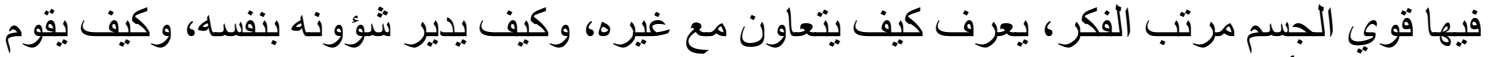

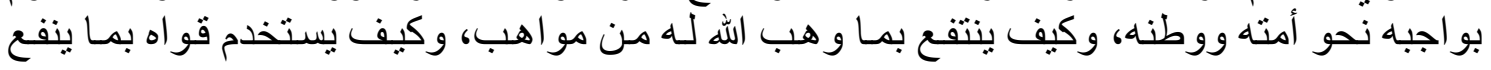

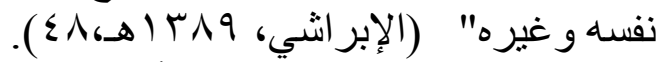

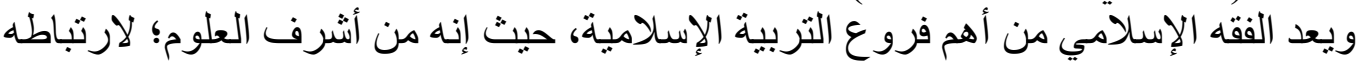

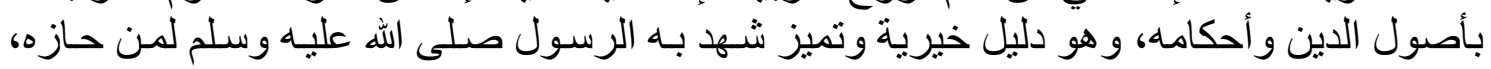

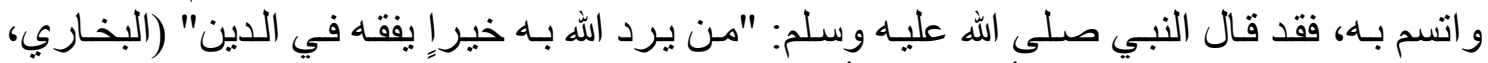

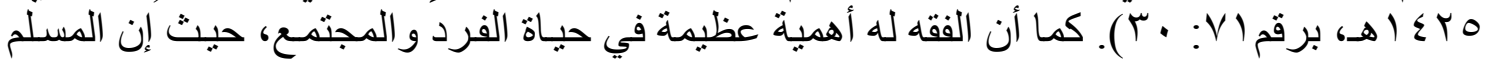

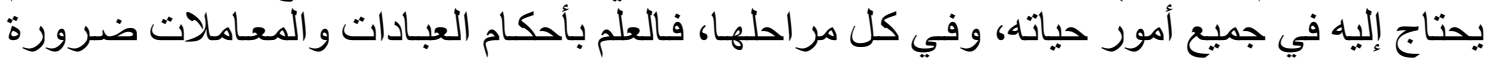

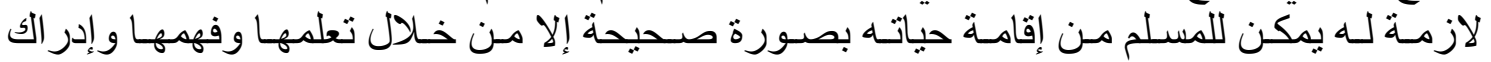

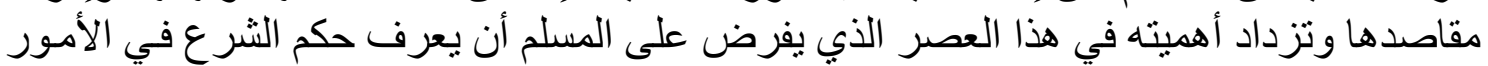
المستجدة من مختلف نو احئ الهي الحياة.

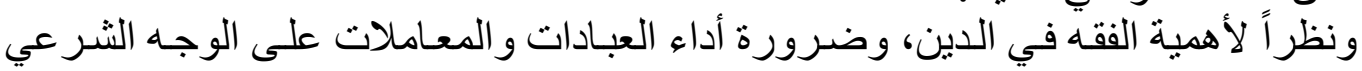

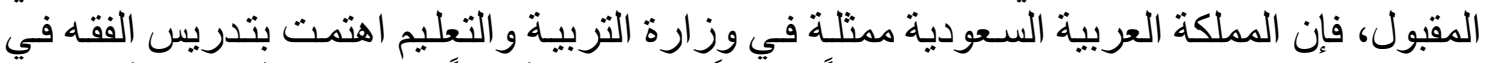

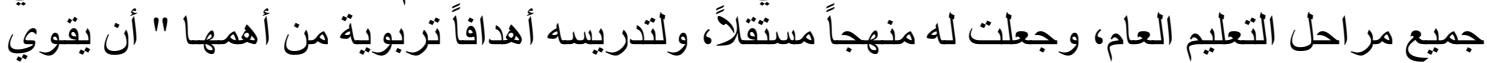

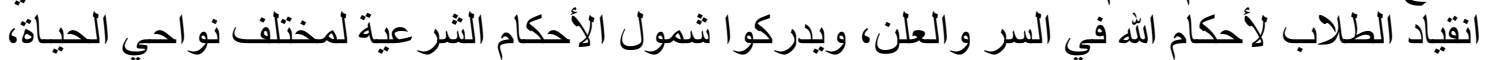

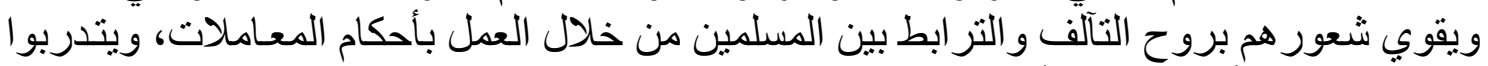

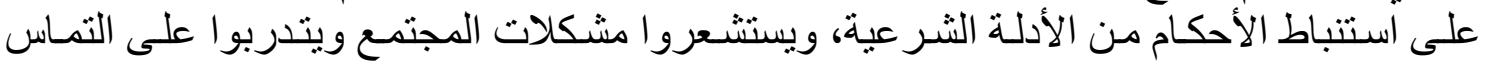




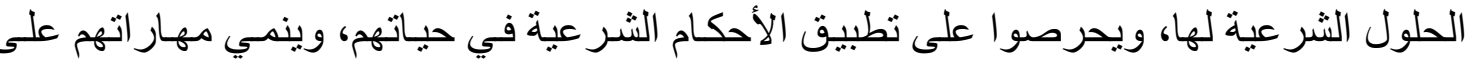

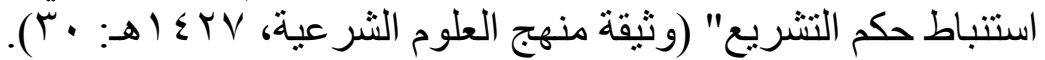

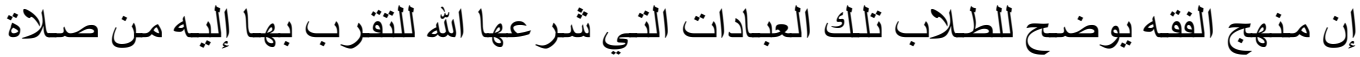
وزكاة وصيام وحج، ويبين لهم أحكامها وشروطها وسننها، و إلا تعذر عليهم القيام بها، و أدائها على

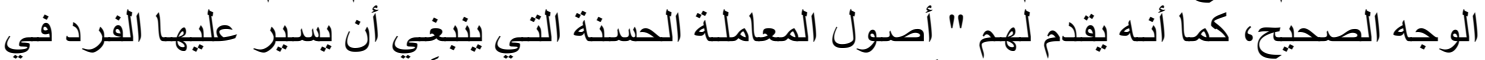

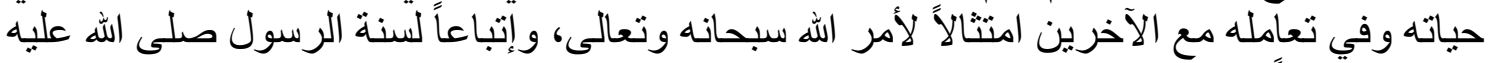

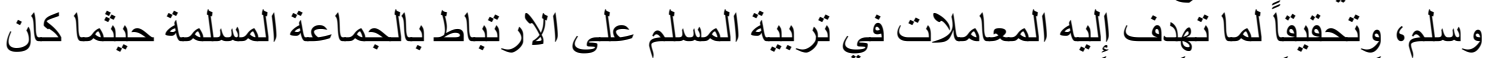

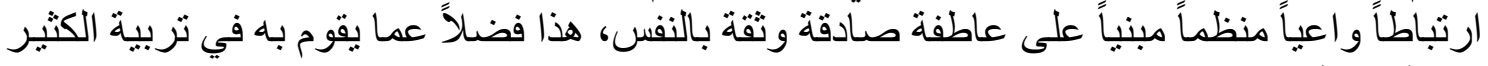

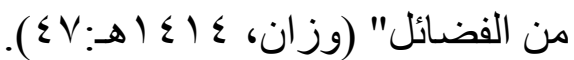

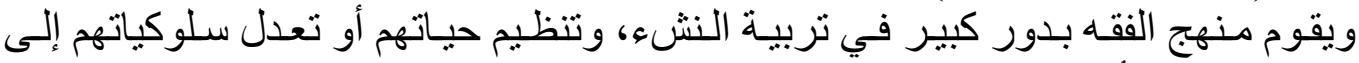

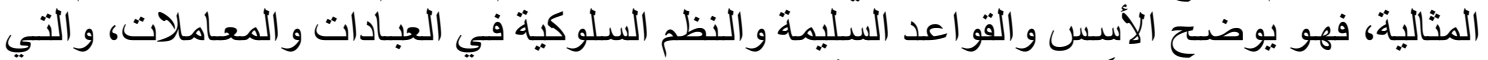

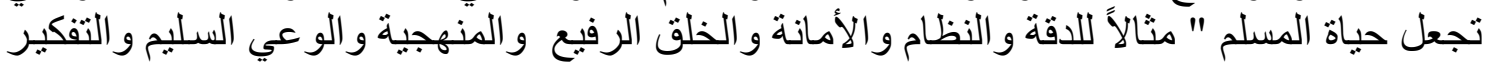

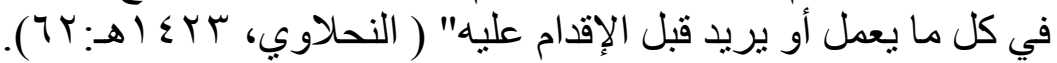

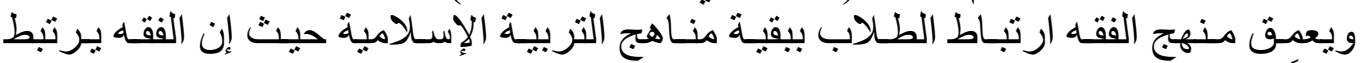

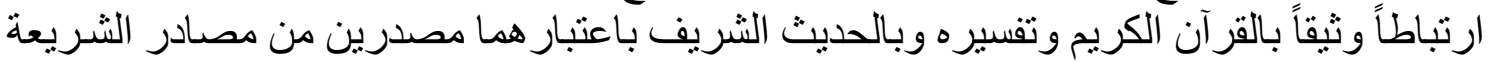

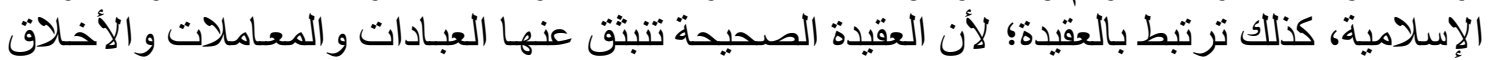
السليمة و القويمة.

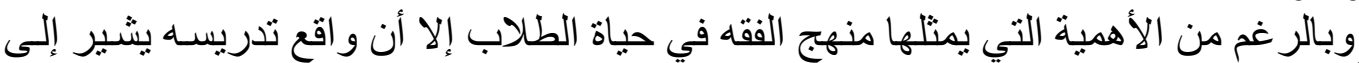

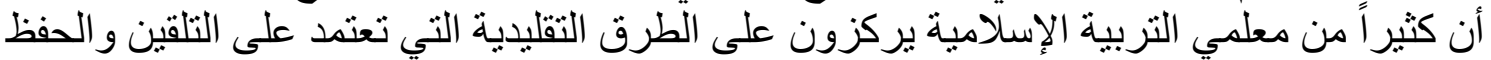

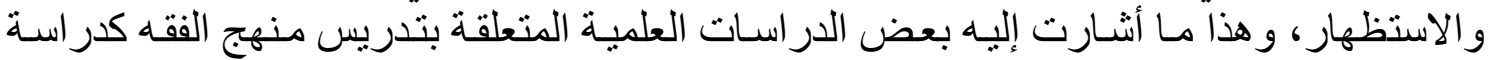

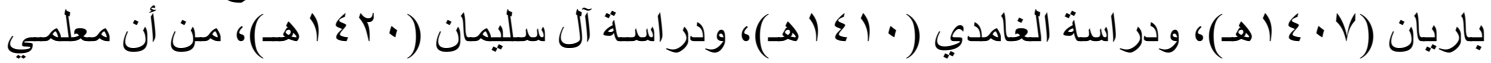

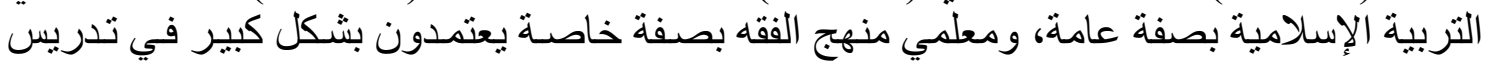

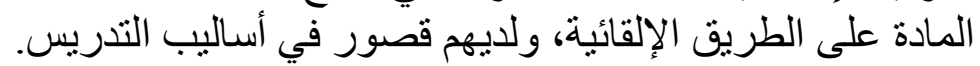

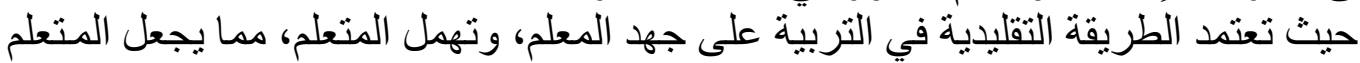

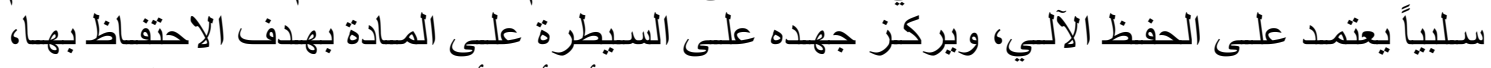

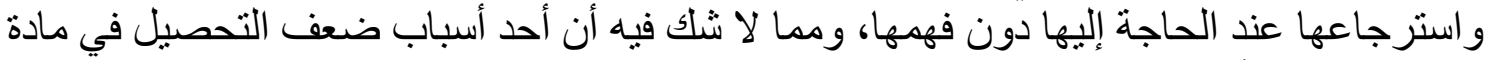

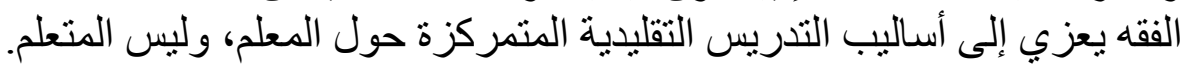

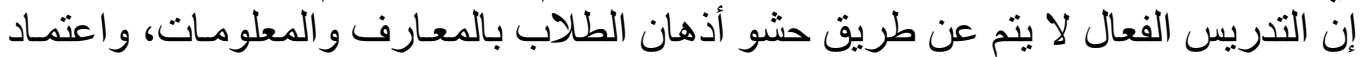

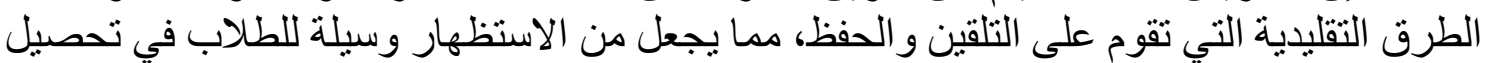

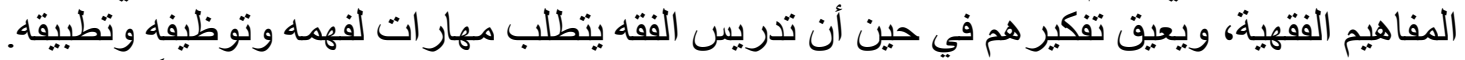

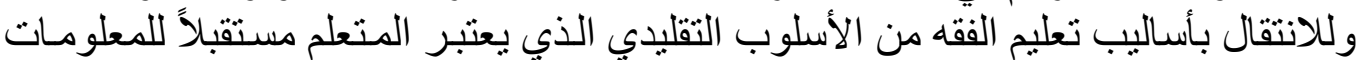

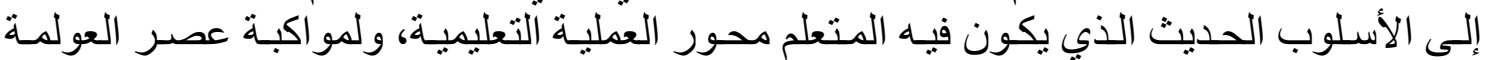

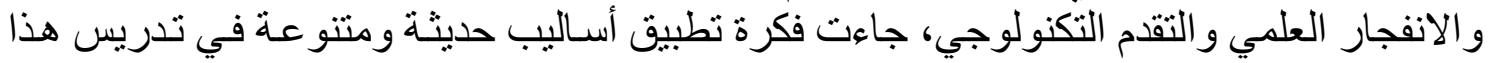

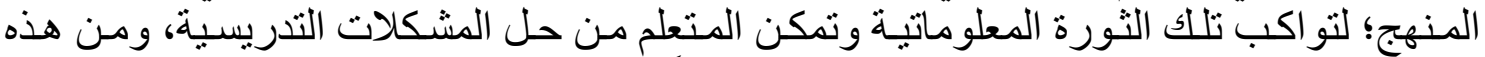

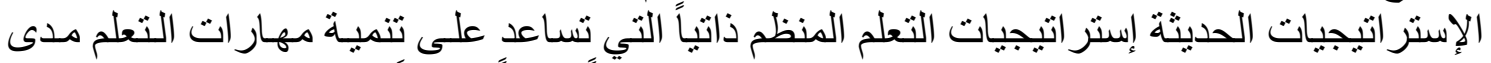

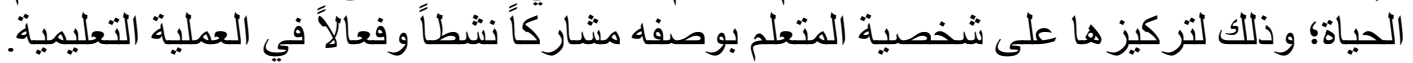

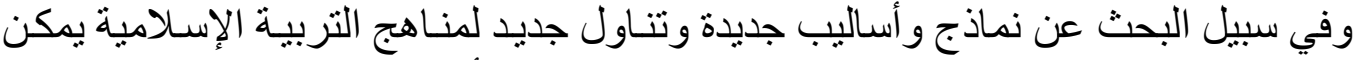

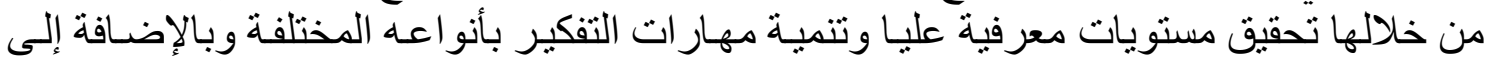

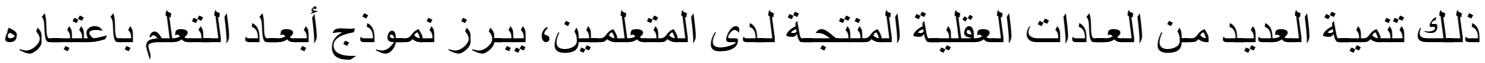




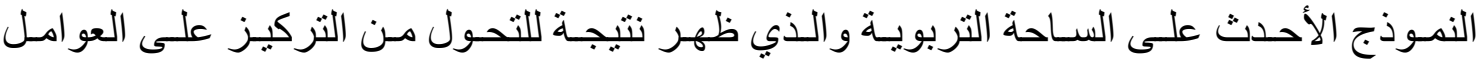

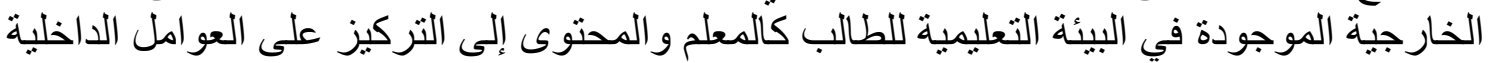

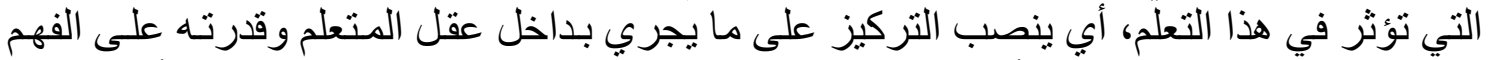

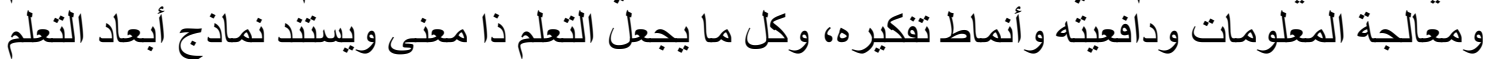

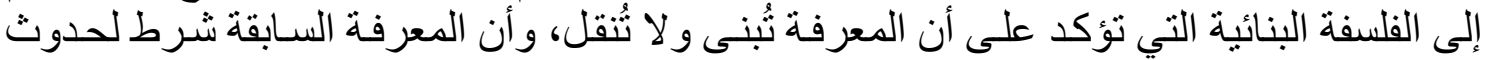

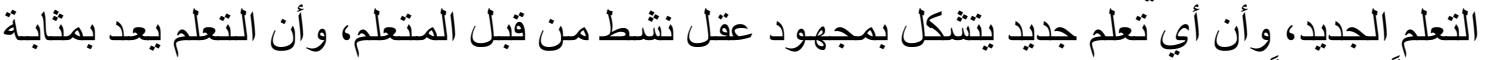

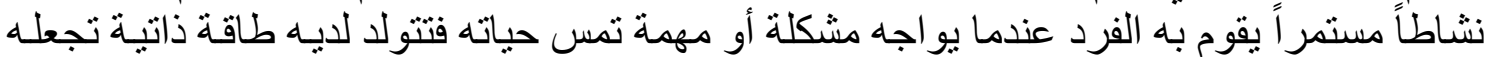

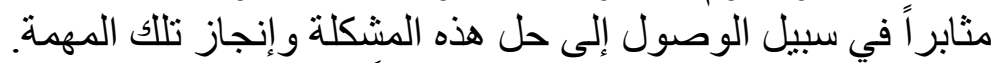

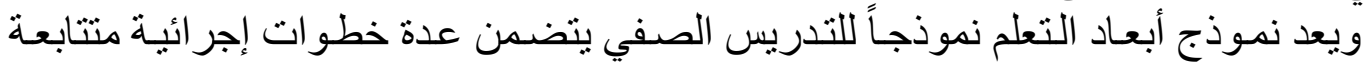

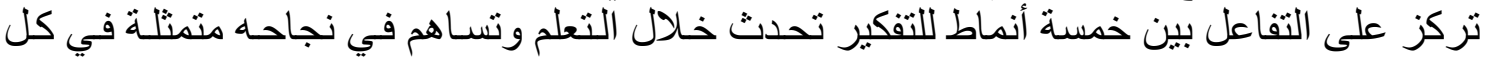

$$
\begin{aligned}
& \text { ا ـ الاتجاهات الإيجابية نحو التعلم. } \\
& \text { r ب اكتساب وتكامل المعرفة. }
\end{aligned}
$$

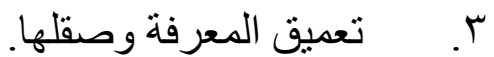

$$
\begin{aligned}
& \text { ع. الاستخدام ذو المعنى للمعرفة. } \\
& \text { •. عادات العقل المنتجة. } \\
& \text { مشكلة البحث: }
\end{aligned}
$$

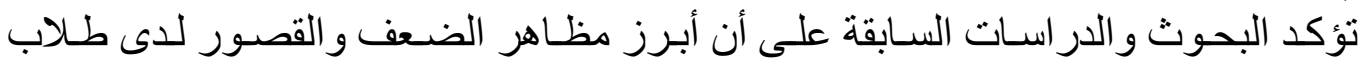

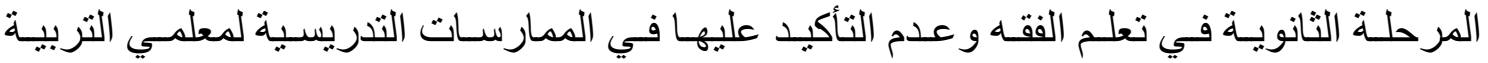

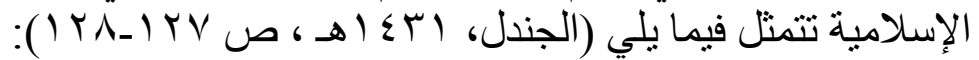

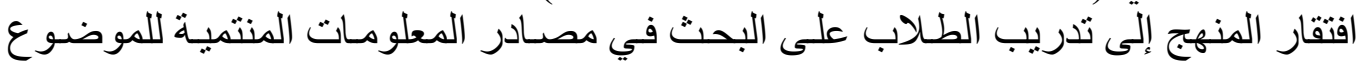

$$
\text { الافتقار إلى وجود فروض للموضو عات الفقهية. }
$$

الافتقار إلى تدريب الطلاب على الاستتباط المستند على الأدلة و البر اهين و الثو الهات الهد.

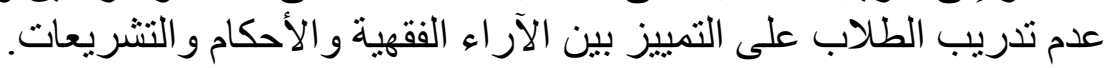

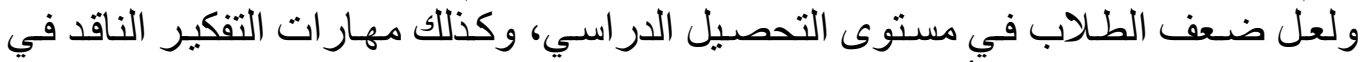

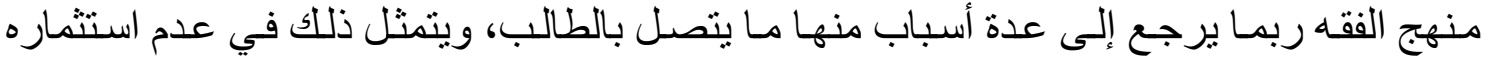

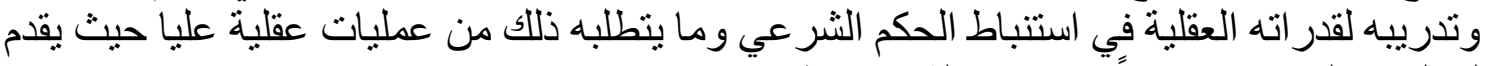

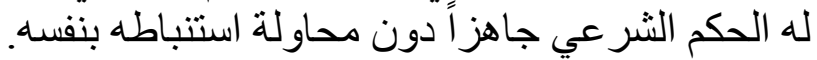

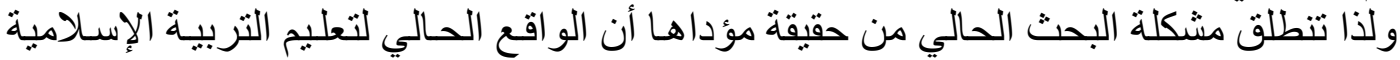

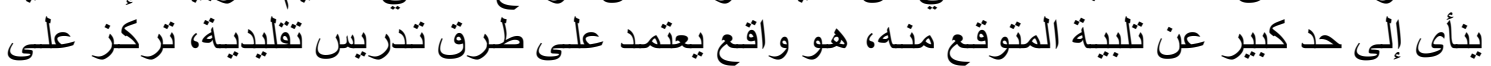

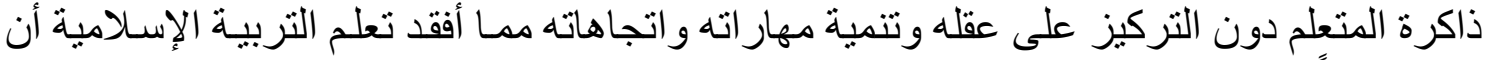

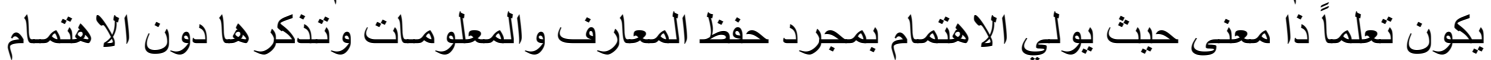

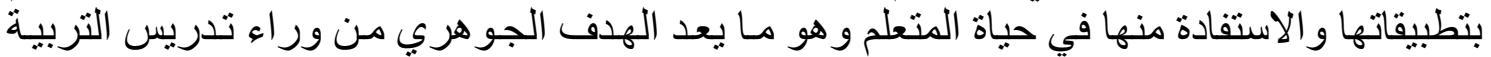
الإسلامية في الأساس.

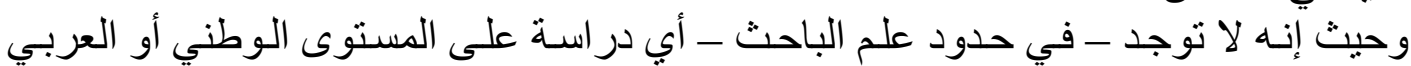

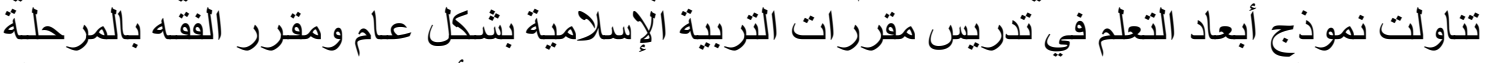

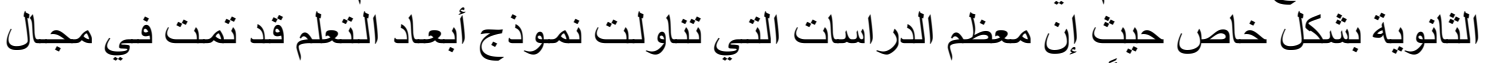

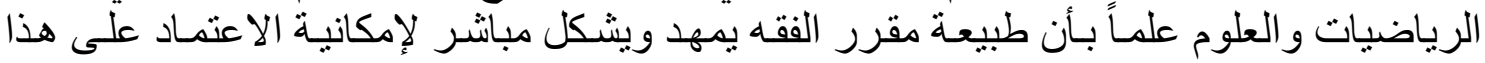


النموذج في التدريس كونه يعني باستنباط الأحكام الثـر عية من أدلتها التفصيلية من جهة التها، وبتعلد وتعليم أمور الدين و الدنيا وفق أُحكام الثريعة الإسلامية مما يحتاج إلى بيئة مناسبة للتعلم و إلى فهم الته

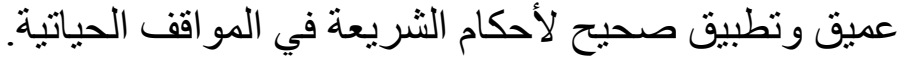

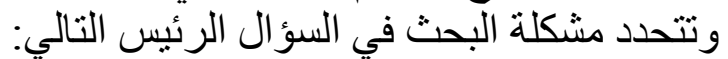

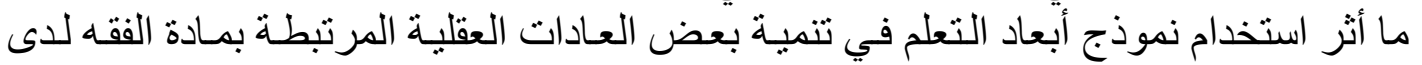

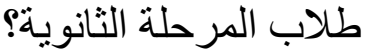
ومن ثم فإن مهمة البحث التالي تتمثل في الإجابة عن الأسئلة الفرعية التالية:

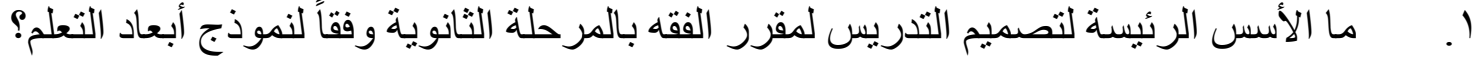

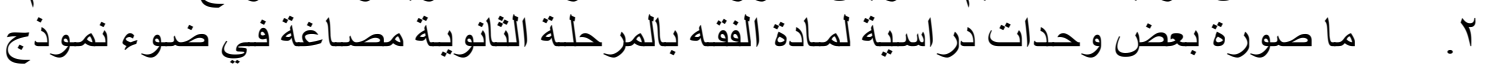

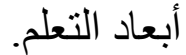

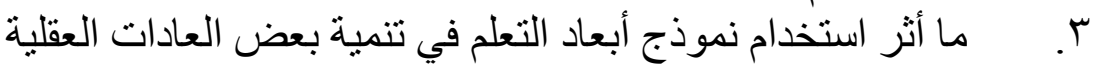

أهداف البحث: أثثر استخدام نموذج أبعاد التعلم في تدريس الفقه للمرحلـة الثانويـة في تنميـة بعض العادات العقلية. أهمية البحث: البحان

يعد البحث الحالي محاولة لإثر اء تدريس الفقه بنموذج بنائي (نموذج أبعاد التعلم) يمكن أن

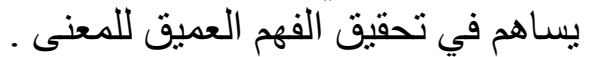
ץ. يوجه هذا البحث الاهتمام نحو إمكانية تنمية العادات العقلية من خلال تدريس مادة الفقه مما

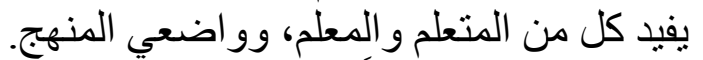

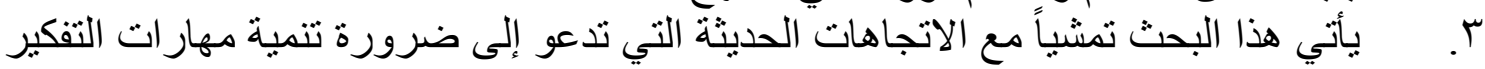

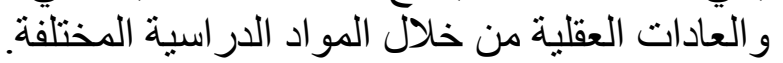

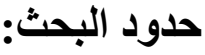

يتحدد البحث الحالي بالحدود التالية:

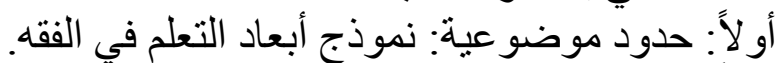

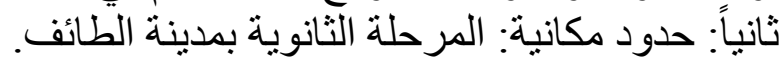

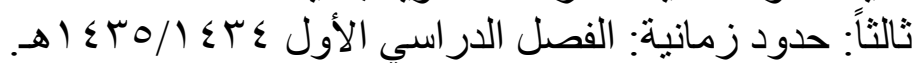

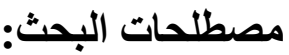

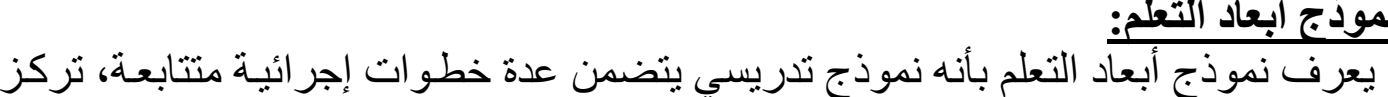

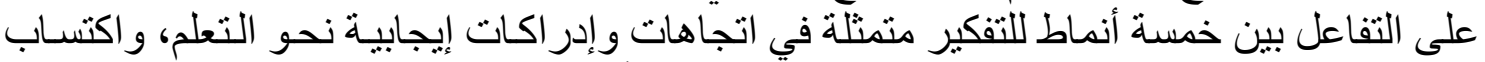

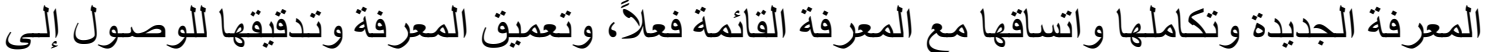

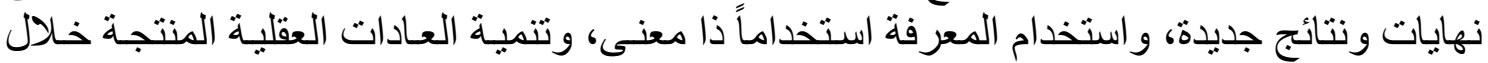
عملية التعلم. عاداث العقل:

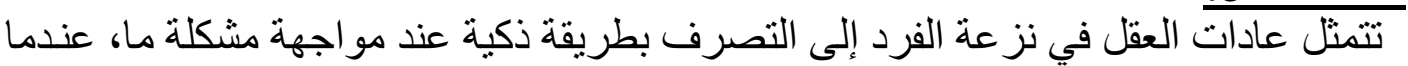

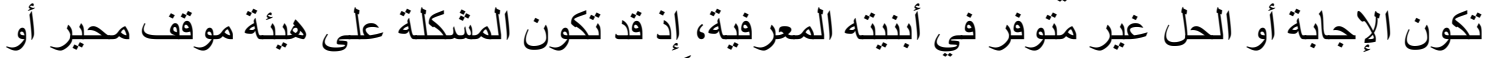

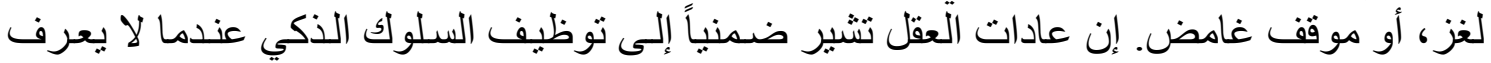
الفرد الإجابة أو الحل المناسب. 
ولقد تعددت تصنيفات العادات العقلية إلا أن الدر اسة الحالية سوف تعتمد على تصنيف كوستا وكاليك Costa \&Kallick لعادات العقل إذ يعد هذا التصنيف من أكثر التصنيفات إقناعاً في شر ح وتفسير وتطبيق العادات العقلية.

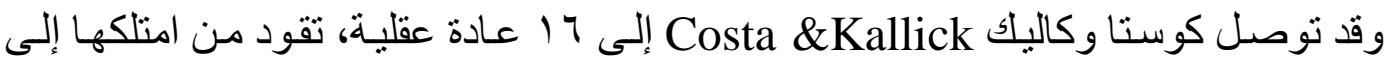

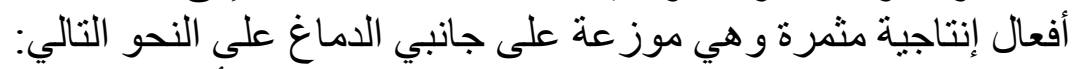

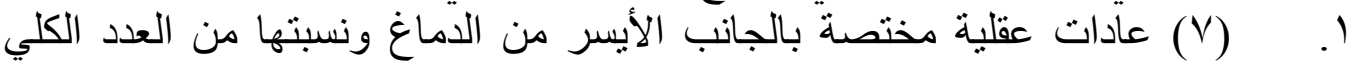

$$
\% \leqslant r . V 0=1 \cdot \times \times(17 \div V)
$$

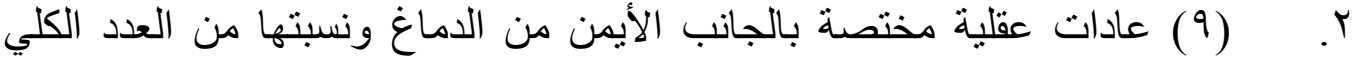

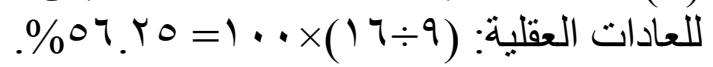
وتتمثل في(7 ا 1) عادة على النحو التالي:

$$
\text { r ـ ـ التحكم في التهور }
$$

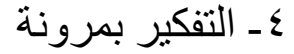

7ـ الكفاح من أجل الدقة فئة

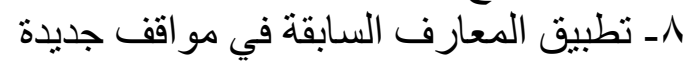

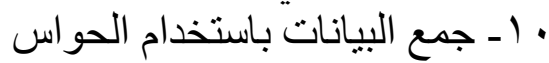

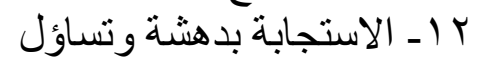

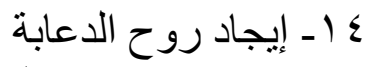

7 ا ـ الاستعداد الدائم للتعلم المستمر الـمر
ا ـ المثنابرة

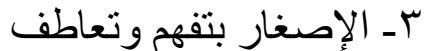
هـ التفكير في التفكير V- التساؤل وطر ح المشكلات

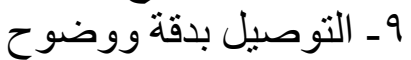
ا 1 ـ التصور و الابتكار و التجديد

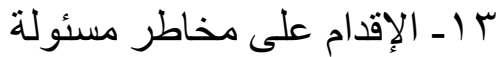
1 ــ التفكير التبادلي أو التشاركي

\section{أدبيات البحثث}

المحور الأول: نموذج أبعاد التعلم أبعاده ومكوناته: أولاً: تعريف نموذج أبعاد التعلم:-

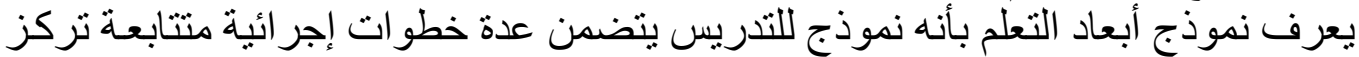

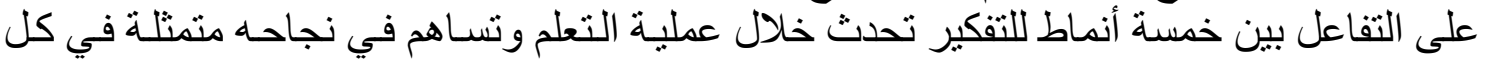

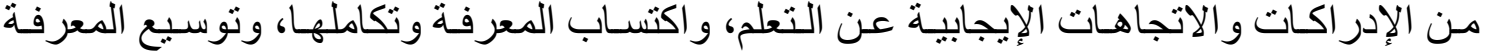

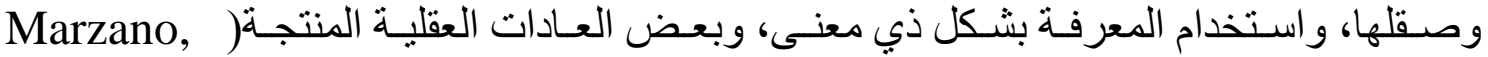

\section{ثانياً: الأنشطة التي يستثل إليها نموذج أبعاد التعلم:-}

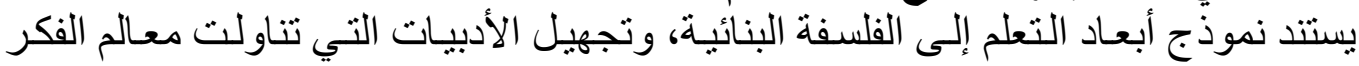

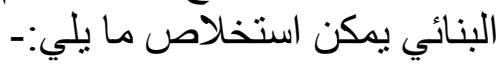

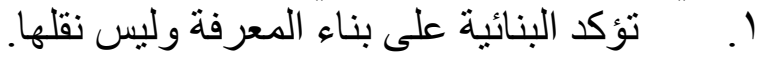

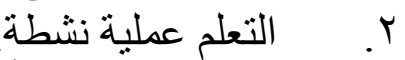

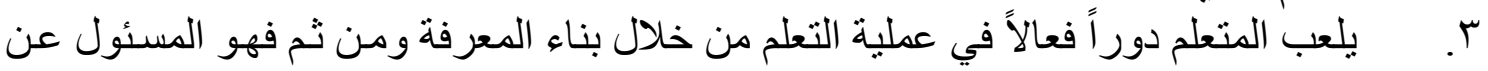
تعلمه وليس المعلم. ع. تعد المعارف و الخبر ات السابقة للمتعلم هي نقطة الانطلاق لأي تعلم جديد حيث يتم تفسير المعرفة الجديدة: في ضوء البنوالية المعرفية القائمة لدى المتعلم.

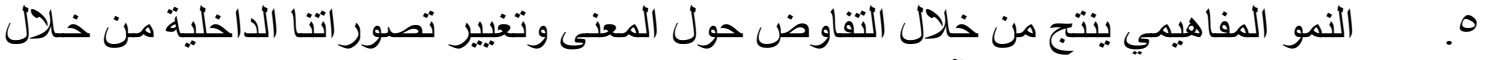
التفاوض الاجتماعي مع الآخرين في بيئة تعاونية هون النية 


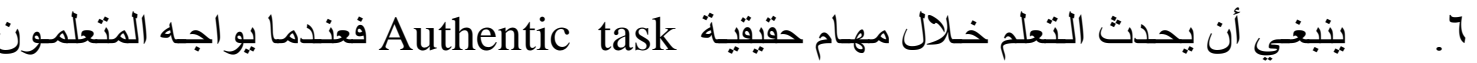

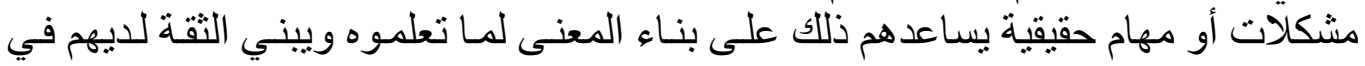

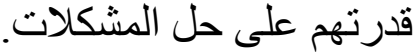

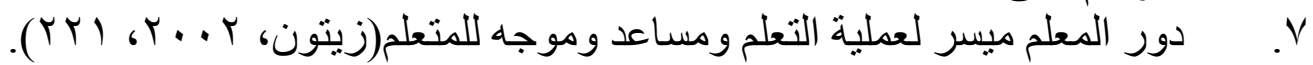
ثالثا: أبعاد نموذج أبعاد التطلم:-

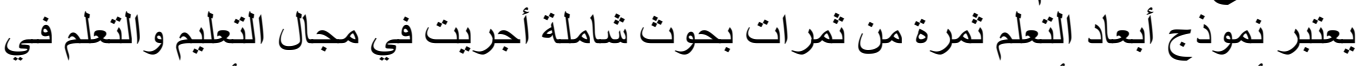

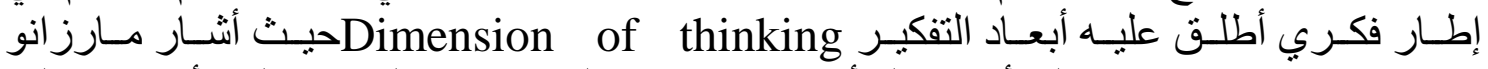
(Marzano, 1998,12)

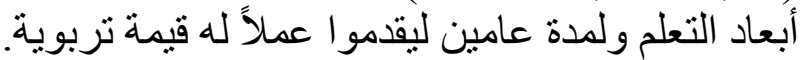

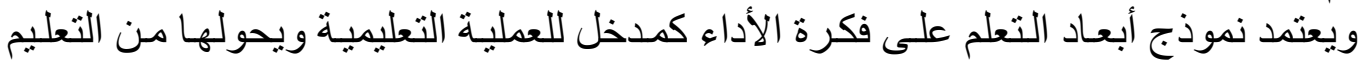

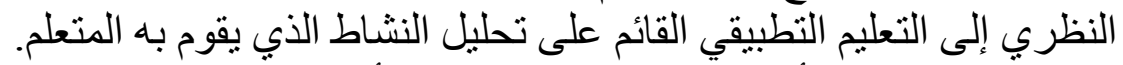

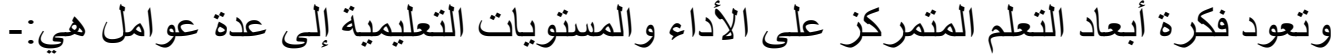

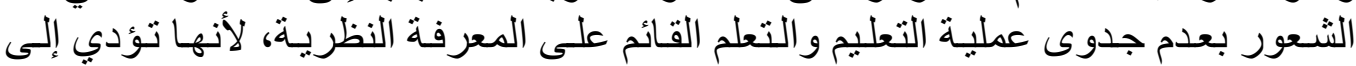

انفصال بين ما تم تدريسه، وبين الأداء و الممارسة في ميدان التعان العمل و والحياة.

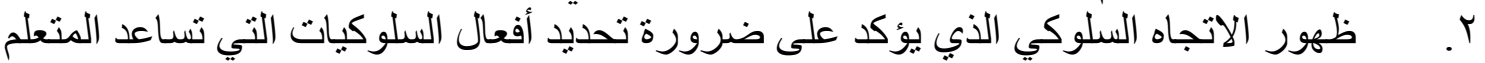

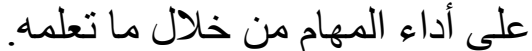
r. الاستتاد إلى الحاجـات المهنيـة و الحياتيـة للمتعلم، وتحديد هذه الحاجـات من خـلال تحليل

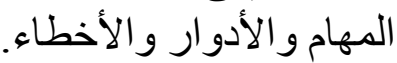

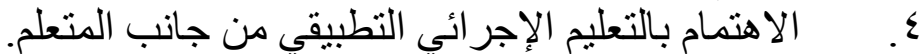

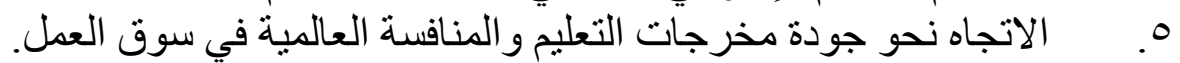

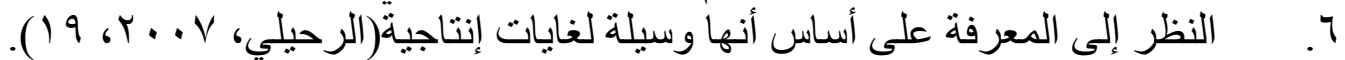

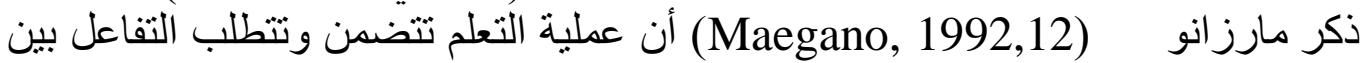
خمسة أنماط من التفكير يمر بها المتعلم أثناء تعلمه أسماها (أبعاد التعلم) وهي كما يليني:Positive Attitudes Toward learning

Acquisition and integration of knowledge

Extending and Refining knowledge

Using knowledge Meaningfully

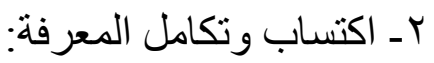

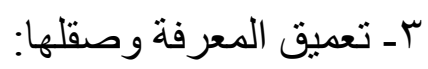

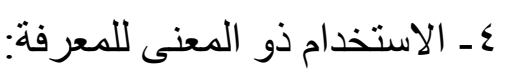

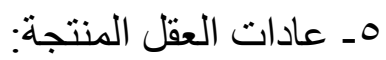

Productive Habits of Mind

المحور الثاني: العادات العقلية: Habits of Mind عرفت بعض المعاجم و الأدبيات كلمة عادة (Habit) بعدة العادة تعريفات منها:-

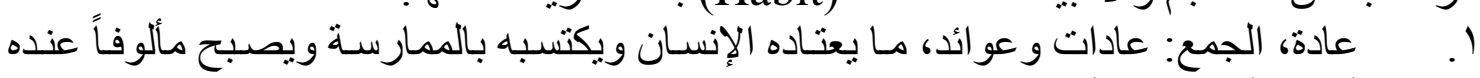

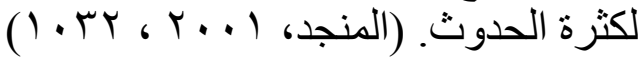




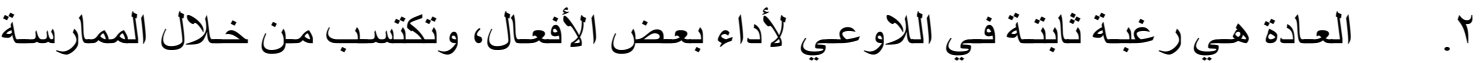

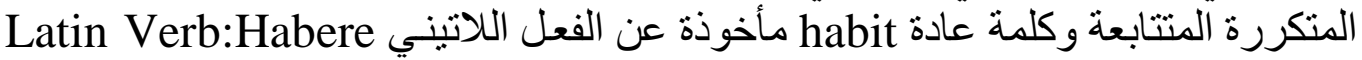

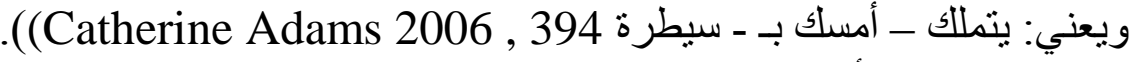
كما عرف العقلّ Mind بأنها:-

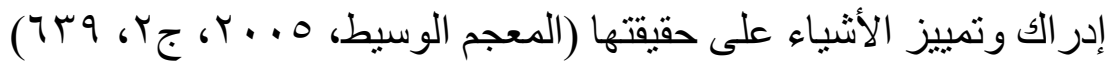
التثبت في الأمور، و التمييز الذي به ينميز الإنسان عن سائر الحيوان (لسان النسان العرب، 999 (1)،

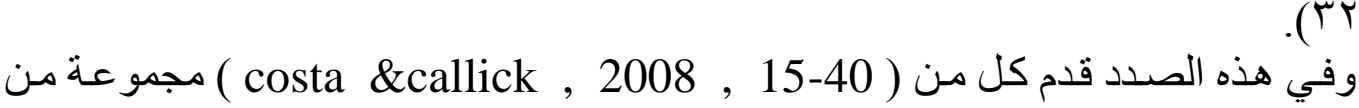
التعريفات لعادات العقل منها:-

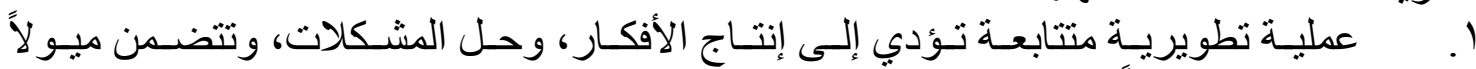

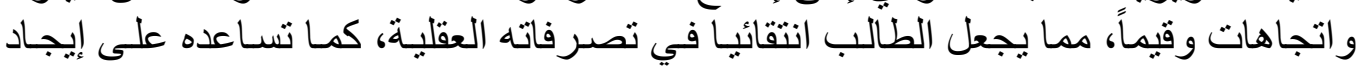
تفصيلات مختلفة.

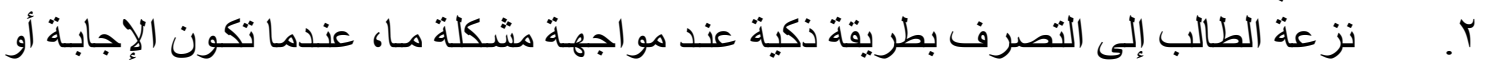

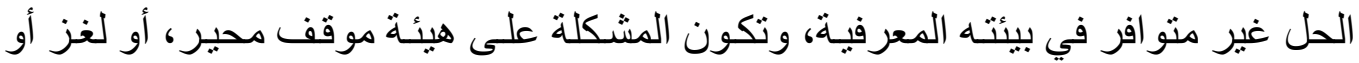

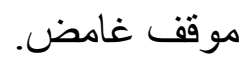

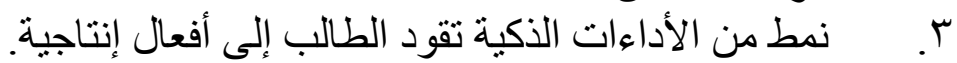

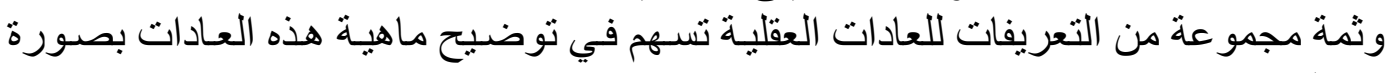

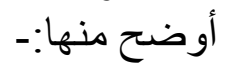
ـ معرفة كيف تتصرف بذكاء عندما تكون لا تعرف الإجابة.

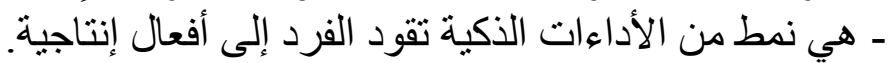

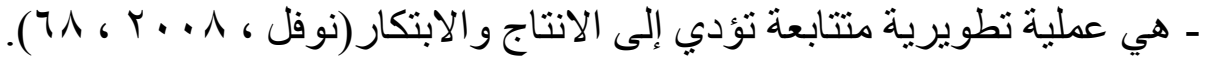

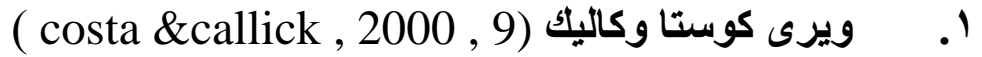
أن أبعاد الإطار الفلسفي الذي تستند إليه عادات العقل تتمثل فيما يلي:أ- رؤية متغيرة نحو الذكاء (الذكاءات المتعددة النعاد)

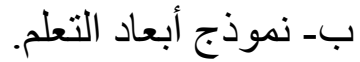
ج- التقنية ومهار ات التعاد التفكير و استر اتيجياته. دـ نتائج البحوث و الدر اسات عن الدماغ البشري

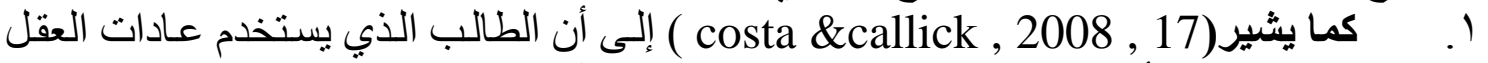
باستمر ار في أنشطة حياته اليومية يتسم بالصفات الآتية:-

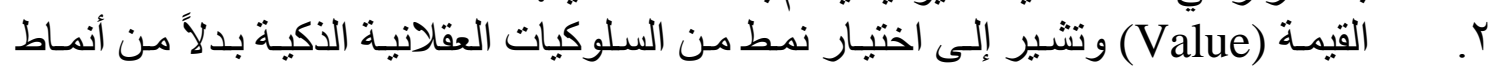

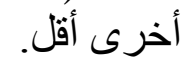
r. الميل (inclination) هو الثعور بالرغبة نحو استخدام نمط من أنماط السلوكيات العقلية

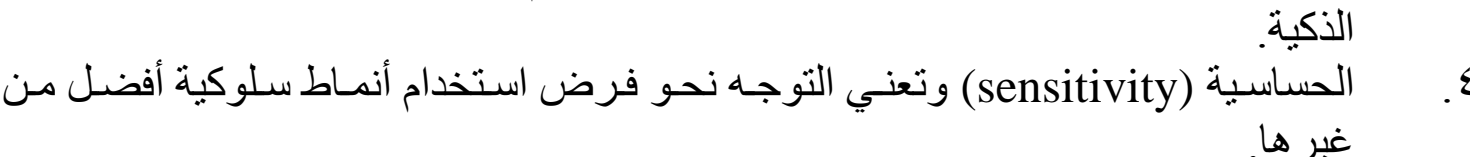
๑. القدرة (Capability) : وتعنسي امتلاك المهار ات و القدرات الأساسية لتنفيذ السلوكيات

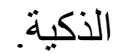
7. الالتزام (Commitment): وتعني مواصلة السعي للتأهل في أداء نمط السلوكيات العقلية، وتحسين مستوى هذا الأداء باستمرار. 
V. السياسة (Policy) : وتعني دمج أنماط السلوكيات العقلية في جميع الأعمال و القرارات وحل المشكلات.

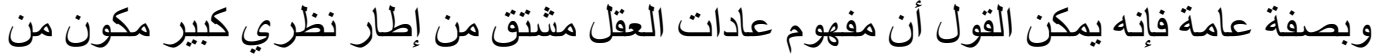

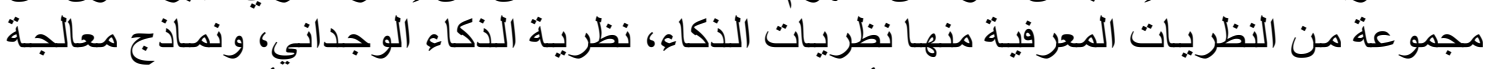

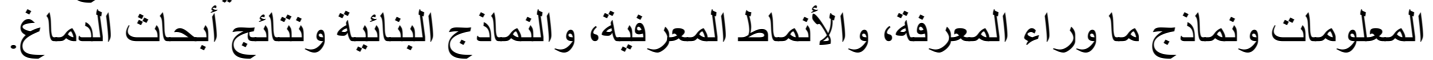

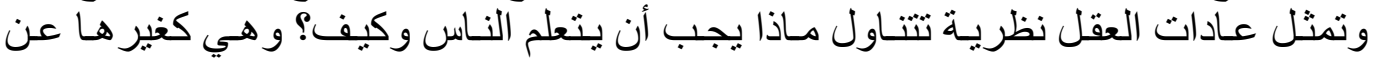
نظريات التعلم تعتمد على أساس من المعتقات وات والقيم، ومن أساسيات ممارسة الفلسفة النقدية للآر اء

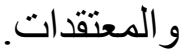

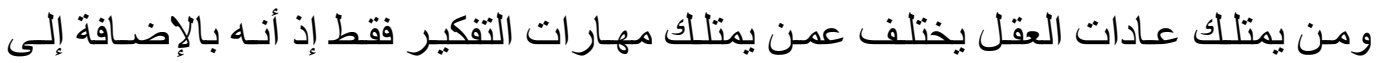

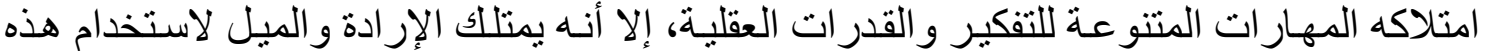

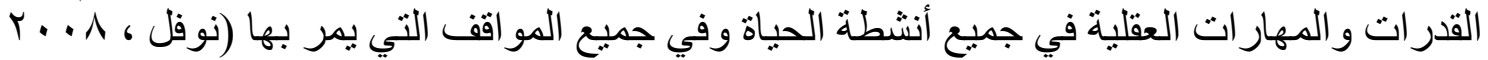

\section{تصنيف العادات العقلية:}

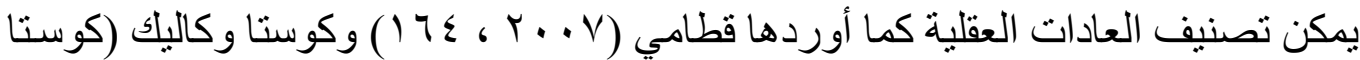

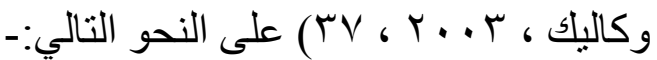

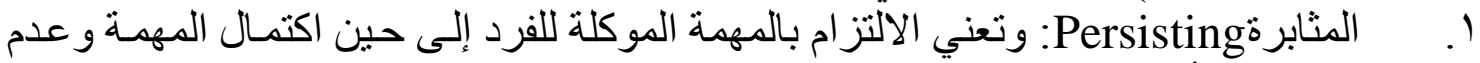

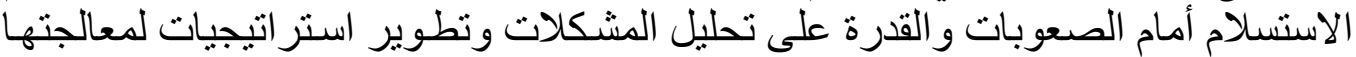

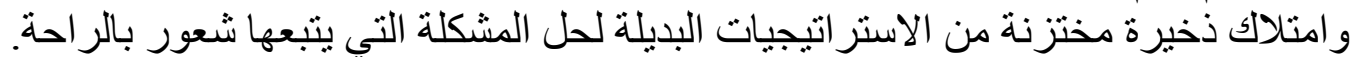

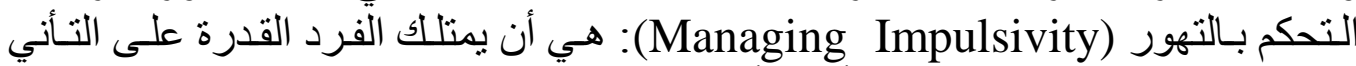

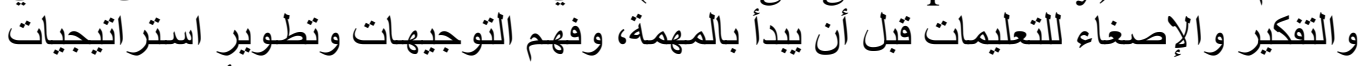

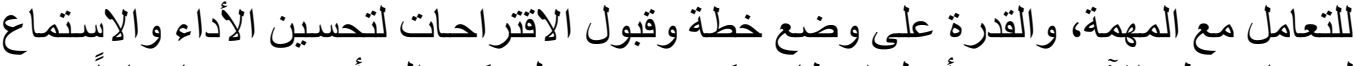

لوجهات نظر الآخرين، وتأجيل إعطاء حكم فوري حول فكرة إلى أن يتم فهمها تماماً.

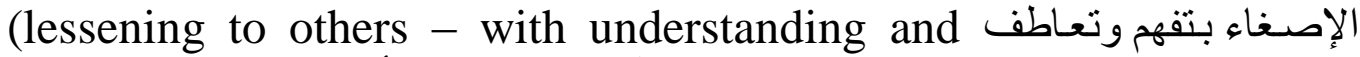
Empathy

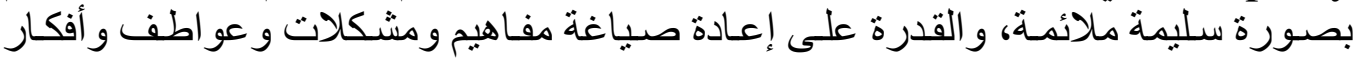
الآخرين بشفافية و إضافة معاني لتوضيحها وانية وتقديم أمثلة عليها.

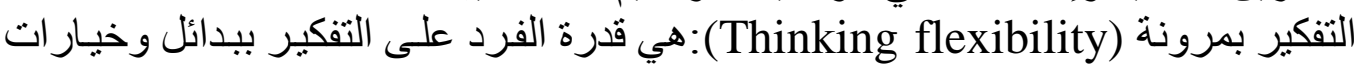

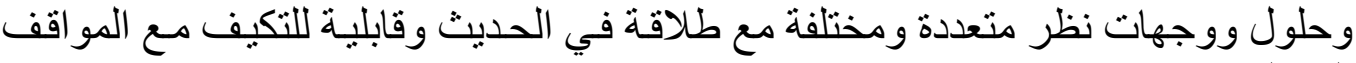

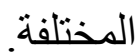

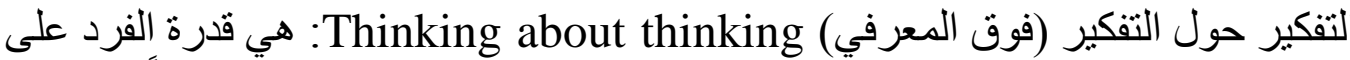

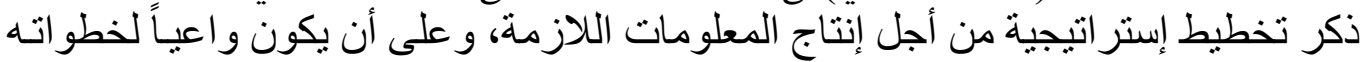

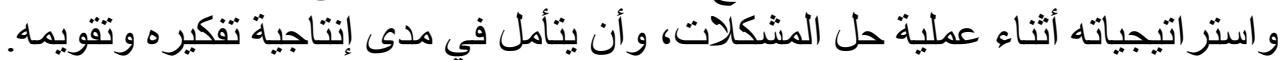

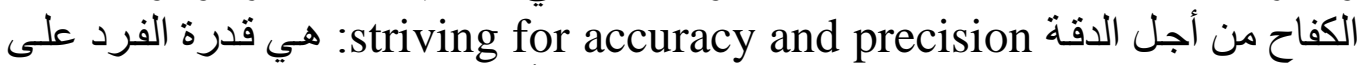

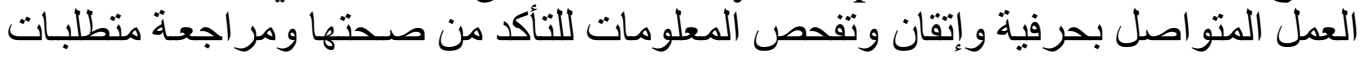

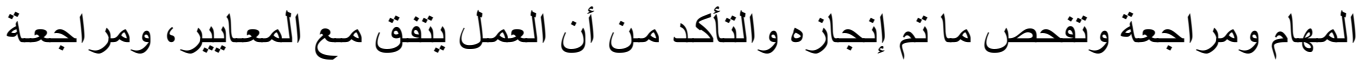
القو اعد التي ينبغي الالتز ام بها.

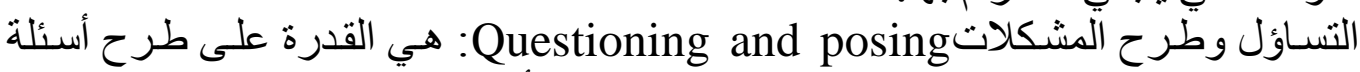

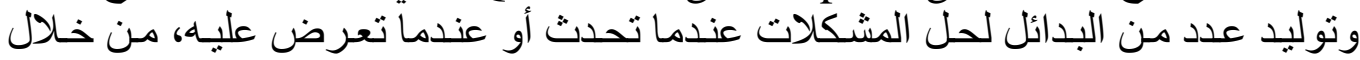
الحصول على معلومات من مصادر متعددة، و القدرة على اتخاذ القر الترار العرض 


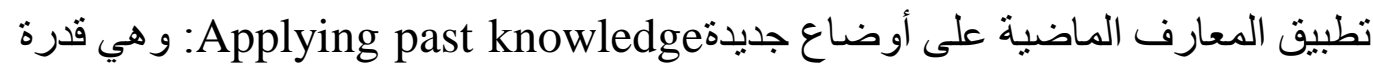

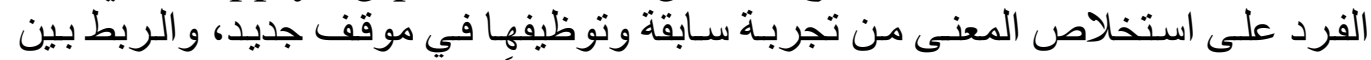

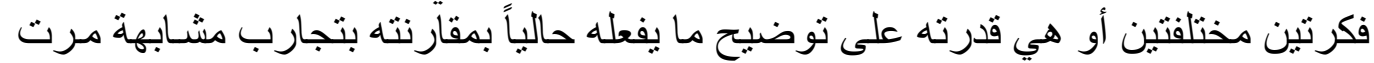

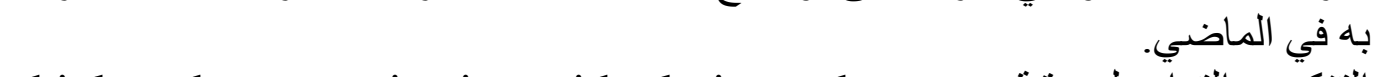

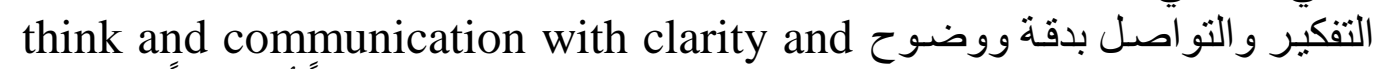
لsrecision

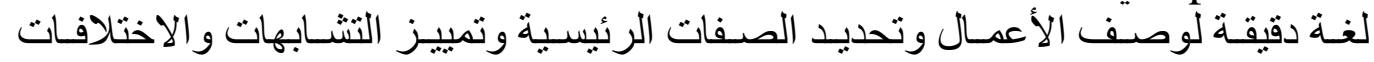

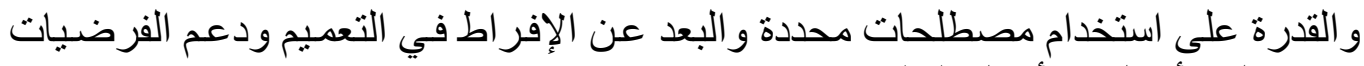
من خلال الأقو ال و الأفعال الدالة.

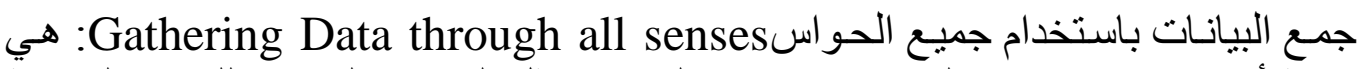

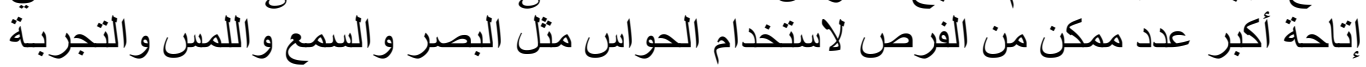

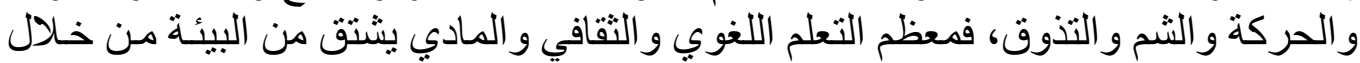
ملاحظة الأشياء أو استيعابها عن طريق الحوأس.

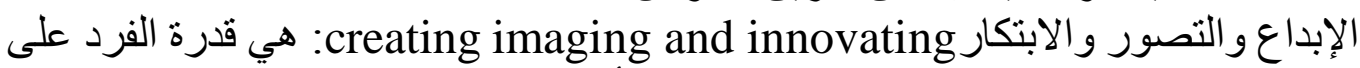

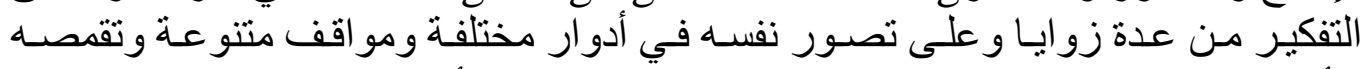

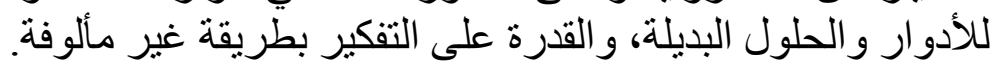
الاستجابة بدهـة ور هبة (الاستمتاع في التعلم) responding with wonderment

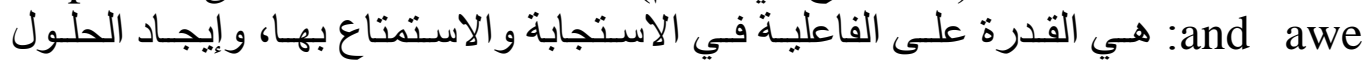

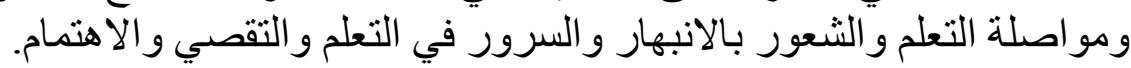

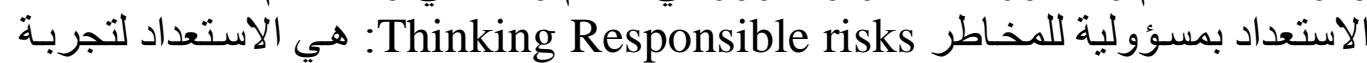

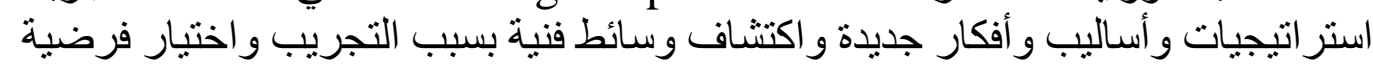

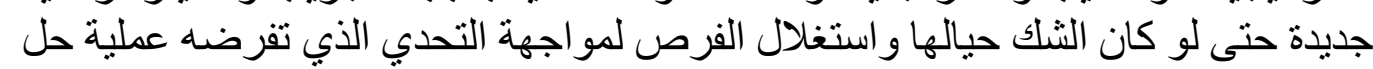

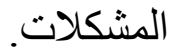

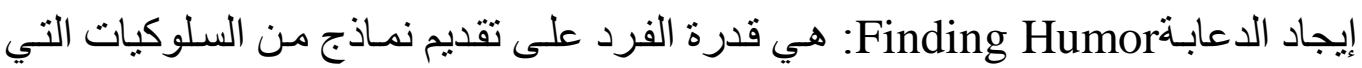

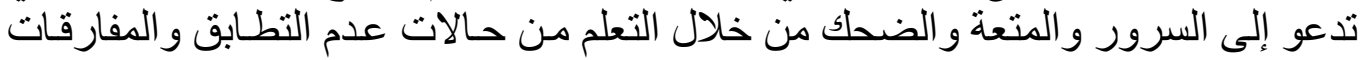

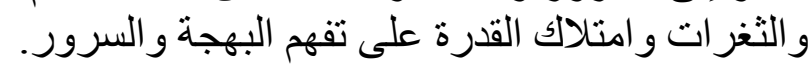

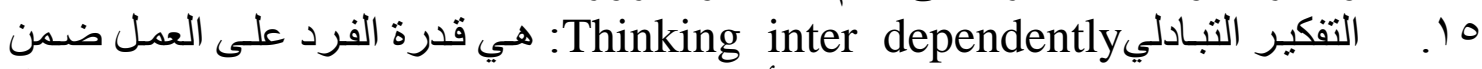

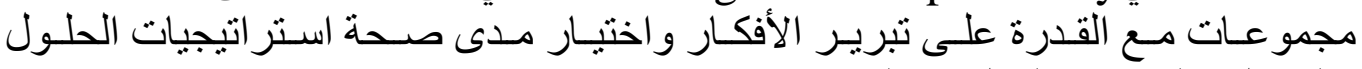

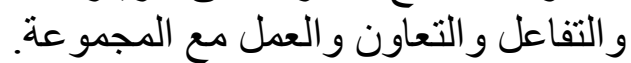

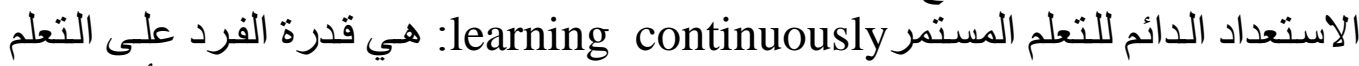

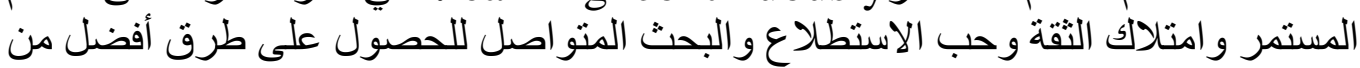
أجل التحسين و النمو و التعلم وتحسين الذات التين.

يمكن تلخيص أهمية تنمية عادات العقلية العقل في أنها تساعد على:ا. تنمية المهار ات العقلية وتعلم أي خبرة يحتاجها الطلاب في المستقبل ومن ثم فهي تؤدي إلى ألى

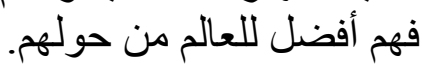
إكساب المتعلم العادات المفيدة له في الحياة كالمثابرة و المرونة والتو الصل الناجح.

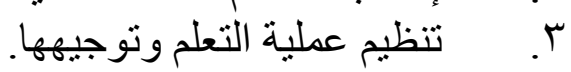


ع. التعلم بكفاءة مع مواقف الحياة اليومية.

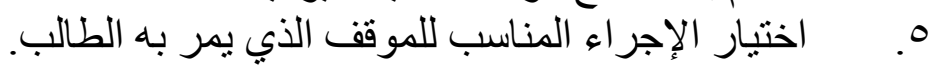

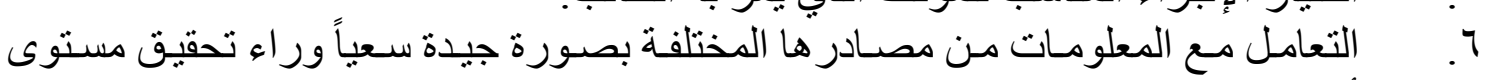

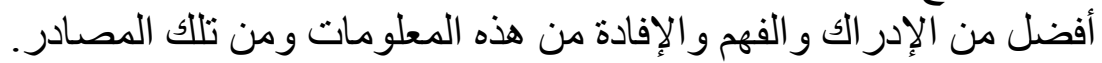

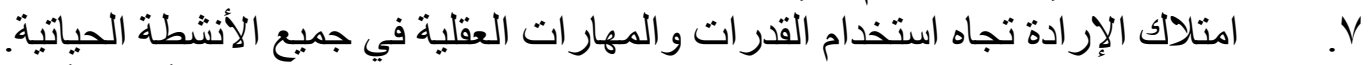

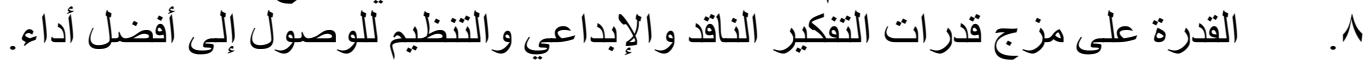

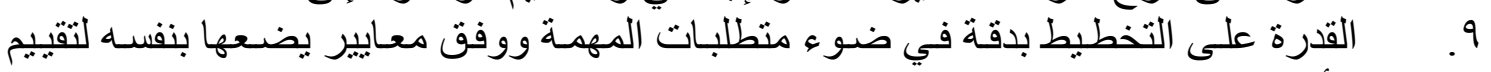
الأداء.

• . . التدريب على تحمل المسئولية وأداء المهام (Costa , 2000) .

ثانيا: الاراسات السابقة:

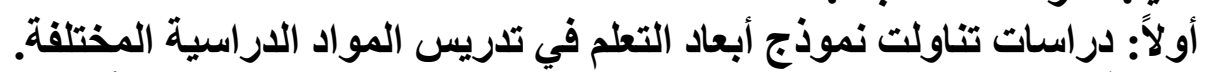

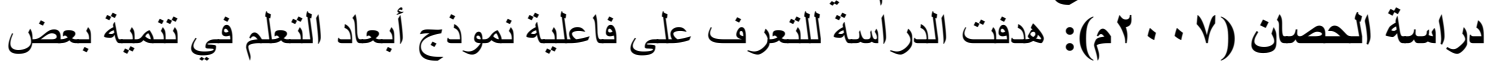

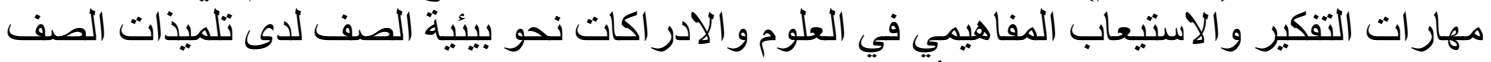

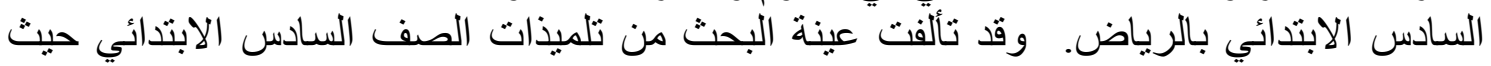

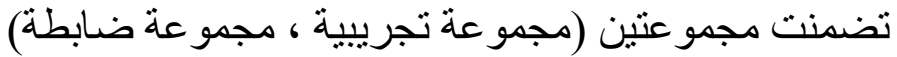

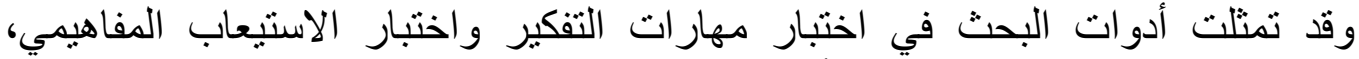

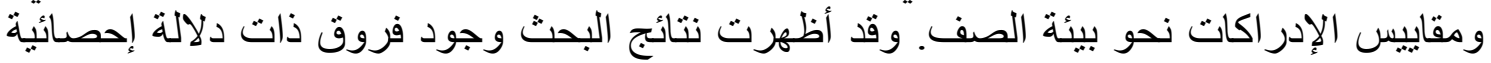

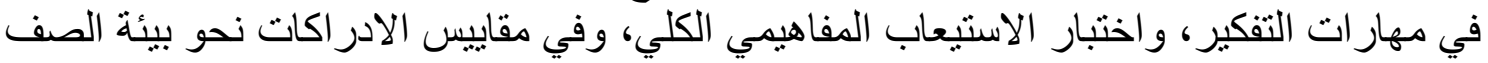
وذللك لصالح المجمو عة التجريبية.

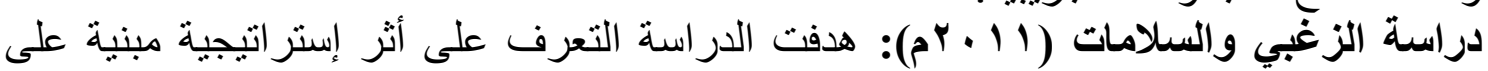

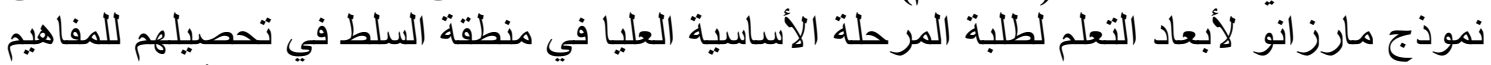

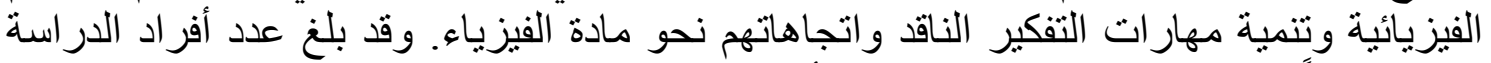

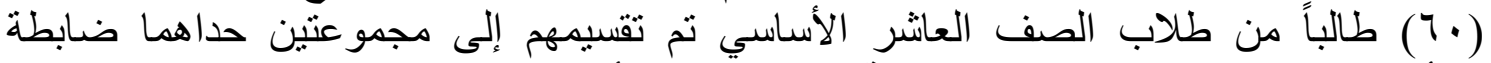

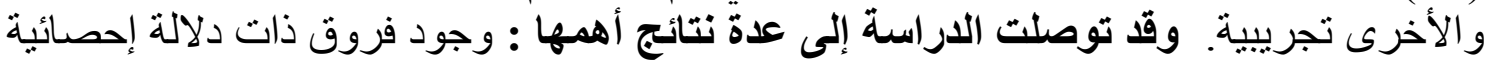

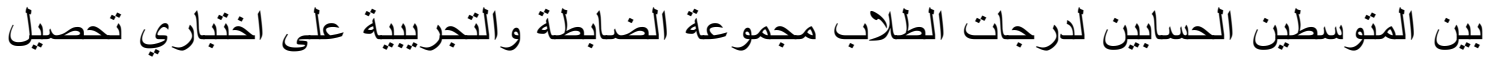

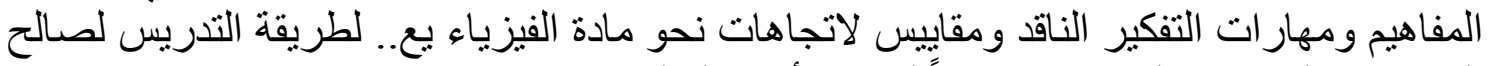

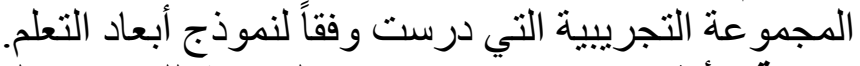

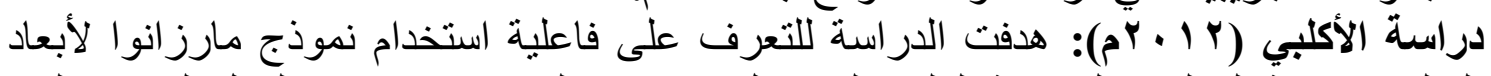

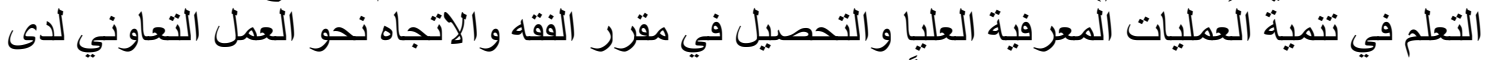

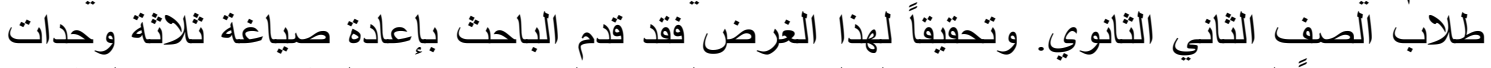

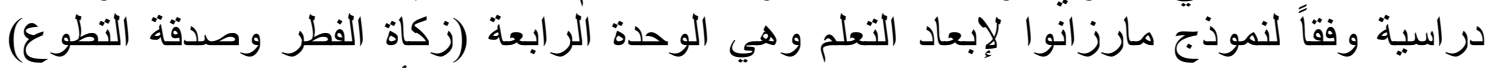

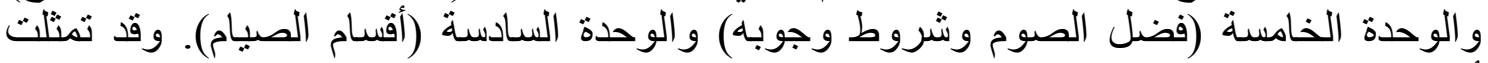

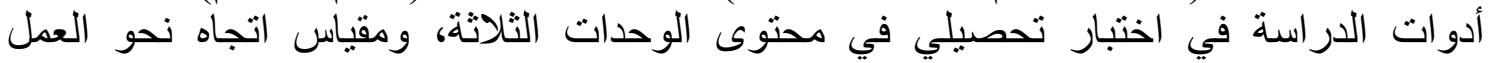
وقد توصلت الداسة إلبعدة نتائج أهمها: وجود فروق ذات دلالة إحصائية بين طلاب

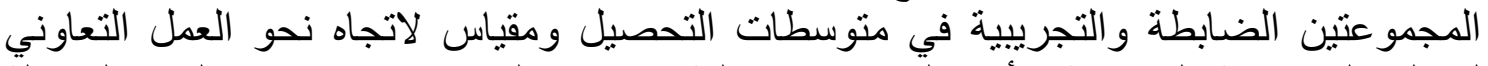
لصالح المجموعة التجريبية الأمر الذي يؤكد فعالية استخدام النموذج في تدريس الفقه بالمرحلة 


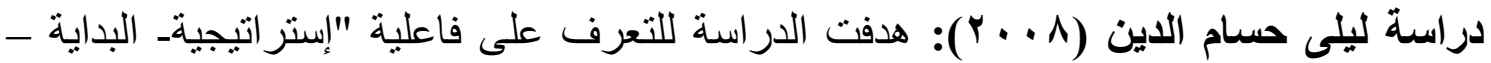

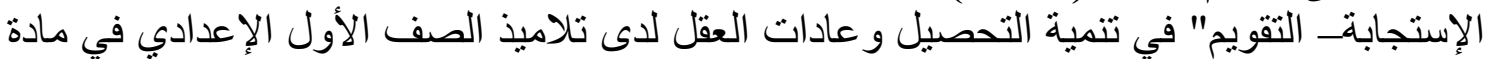

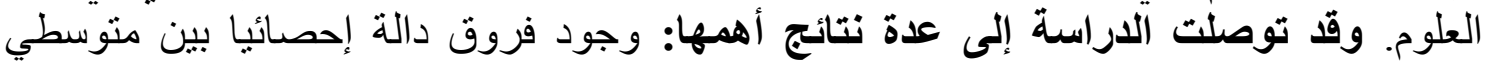

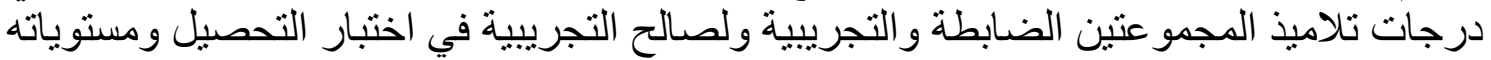

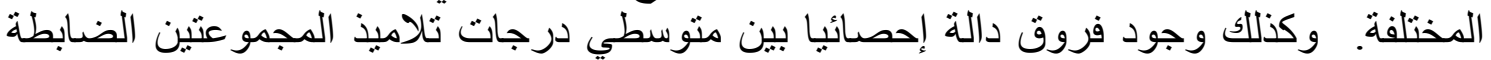

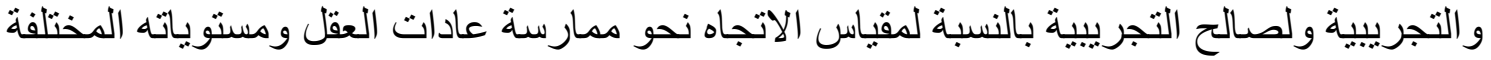
ومهارة التنظيم الذاتي ـ مهار ات التفكير الناقد ـ مهار ات التهات التفكير الابتكاري. وكذلك بالنسبة للمهار ات العقلية المكونة لعادات العقل ومهار اته المختلفة.

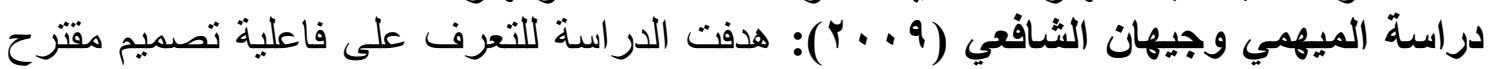

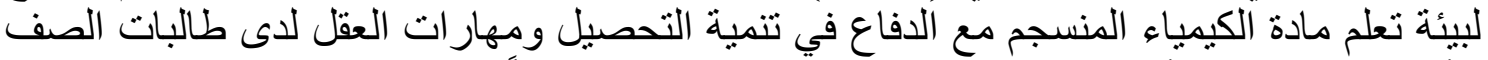

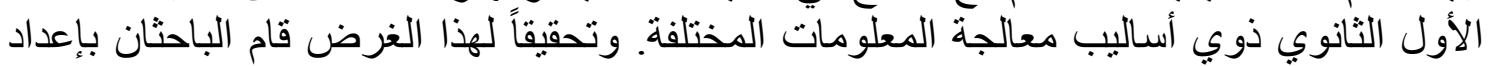

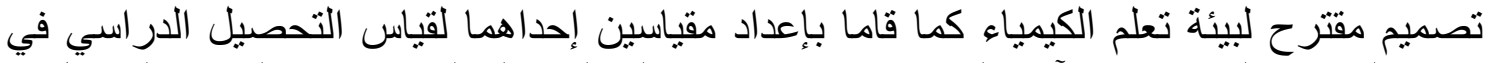

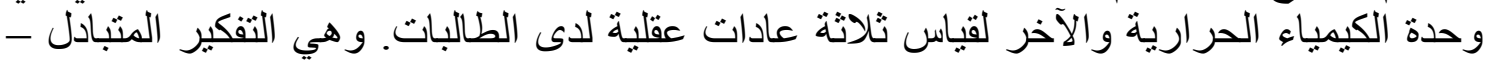

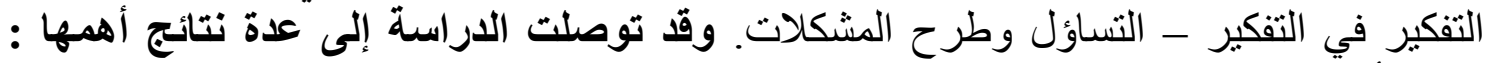

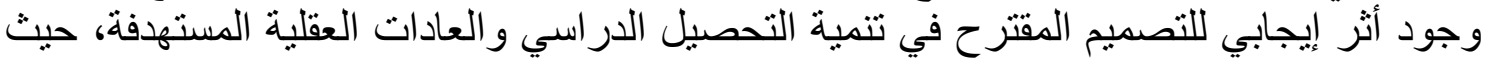
بينت الدراسة وجود فروق دالة إحصائيات بين منوسطي درجات الكسب التبات الفعلي في مقياس

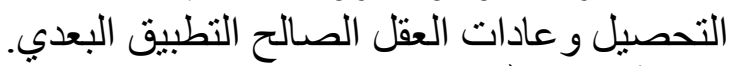

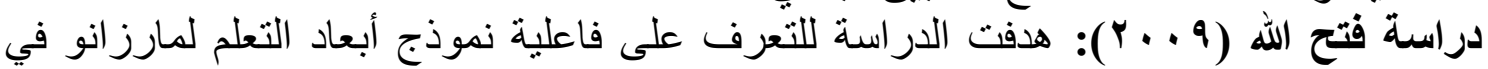

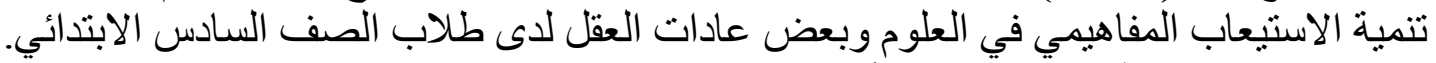

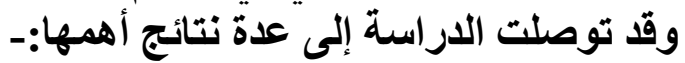

وجود فروق ذات دلالة إحصائية بين المتوسط المدان المعدل لدرجات طلاب المجموعة الضابطة

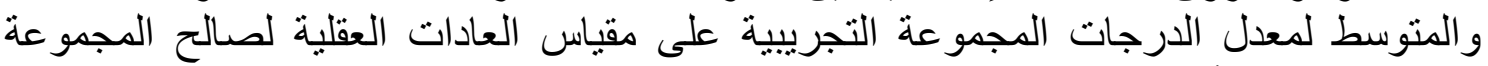
التجريبية وبحجم أثر كبير.

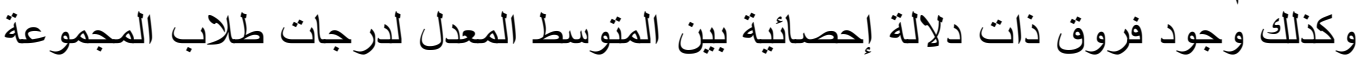

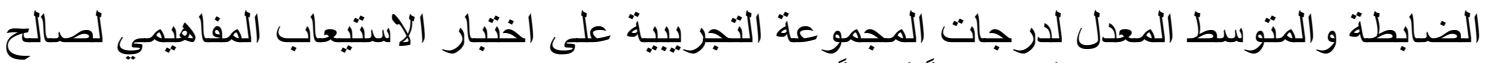
المجمو عة التجريبية وبحجم أثر كبير أ أيضاً.

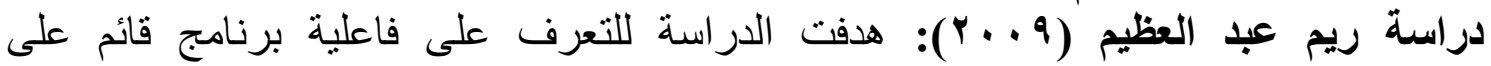
استر اتيجيات التفكير المتشعب في تنمية مهار ات الكتابة الإبداعية وبعض هادية عادات العقل لادى تلاميذ

وقد توصلت الاراسة إلى عدة نتائج أهمها: وجود فرق ذات دلالة إحصائية بين متوسطات

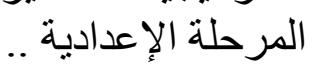

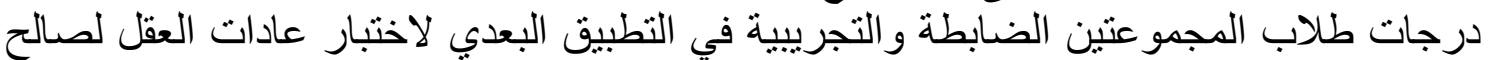
المجموعة التجرييية. كما كان حجم التأثير على مستوى تنمية العادات ككل وكذلك في كل مادة عقلية على حدة.

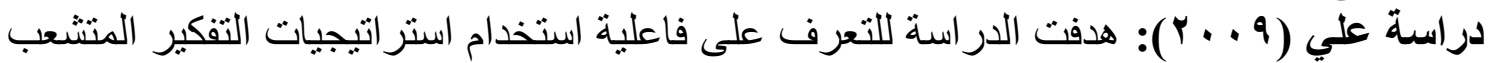

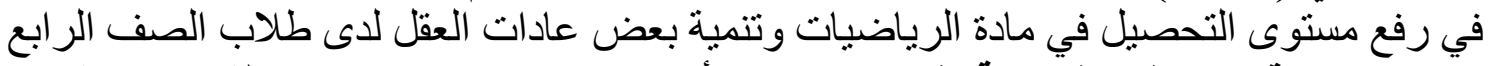

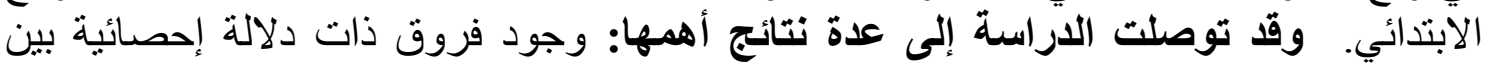

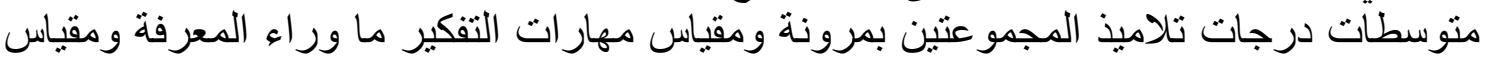




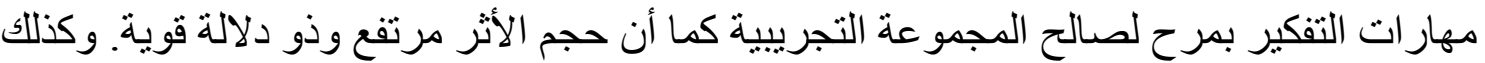

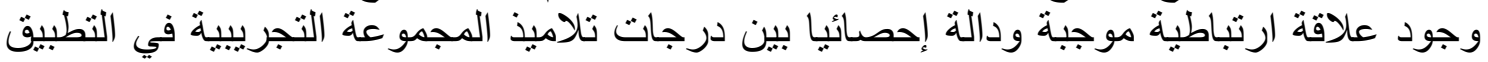

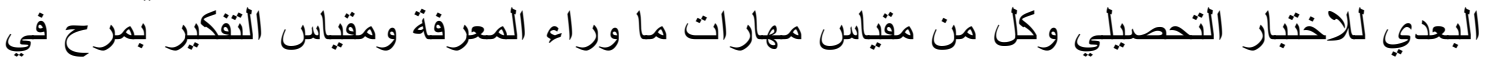

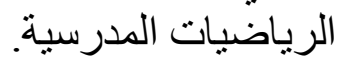

\section{إجراءات البحث}

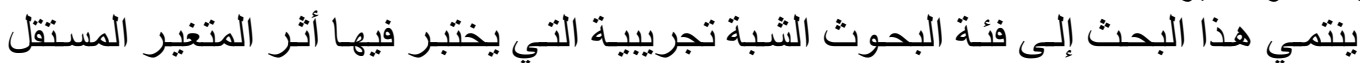
منهج البحث ومتفيراته :

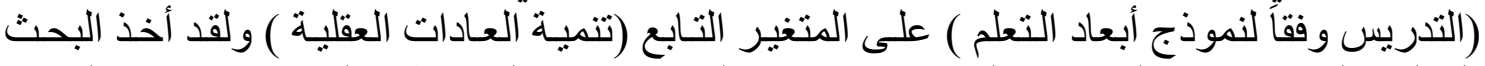

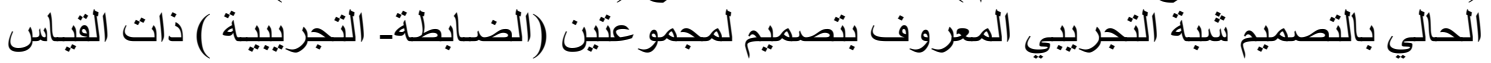

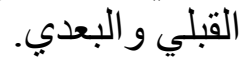

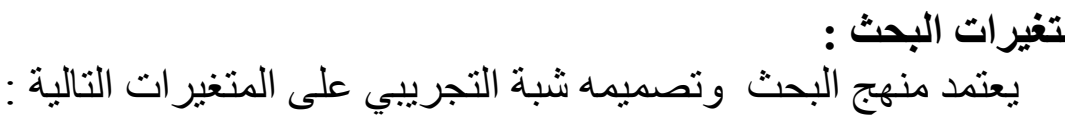

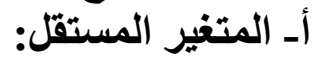

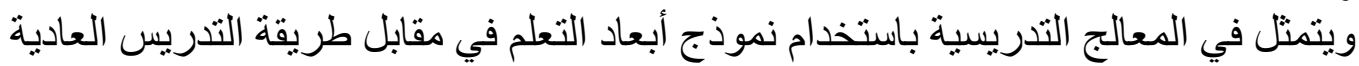
ب - المتغير التابع : بعض العضادات العقات العقلية وتقاس بمقياس للعادات العقلية من إعداد الباحث.

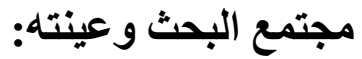

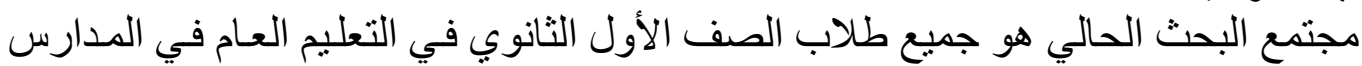

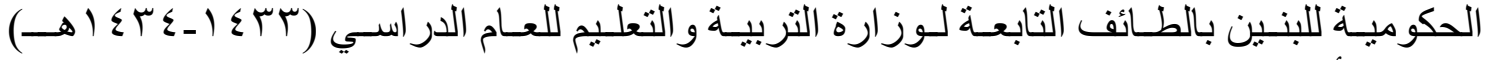

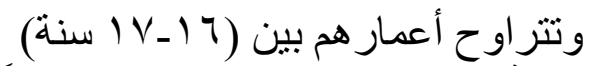

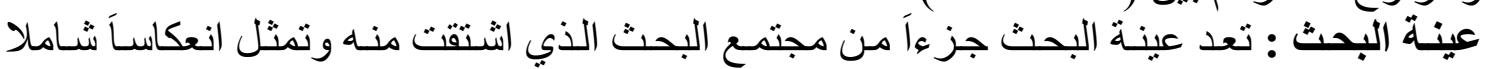

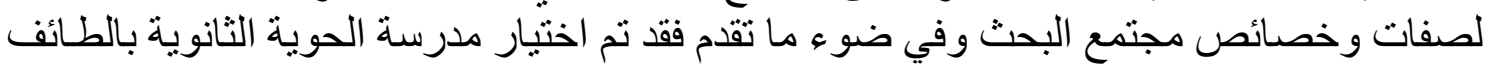
وذللك لما يلي : عدد طلاب المدرسة مناسب لإجر اء تجربة البحث. .1

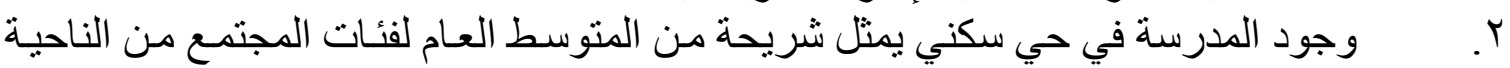
الاقتصادية و الاجتماعية و الثقافية .

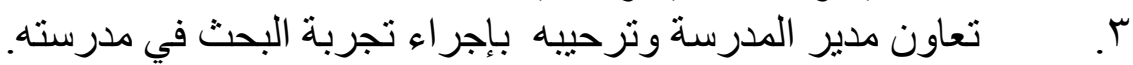

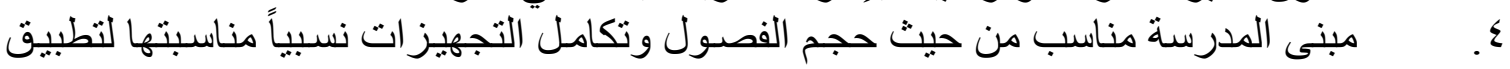
تجربة البحث.

•. استعداد معلم الفقه في المدرسة للقيام بكل ما يتطلبه تتفيذ نموذج أبعاد التعلم أثناء التندريس .

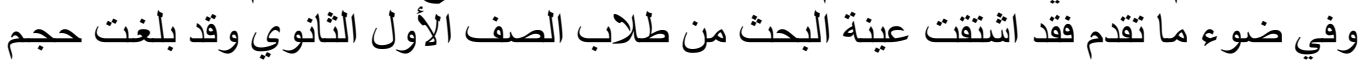

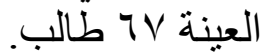

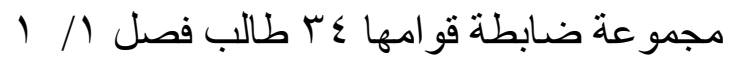

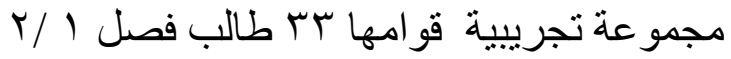
أولا إعداد المادة التعليمية:

تم اختيار الوحدات الثلاثة الأولى من مقرر الفقه بالصف الأولى الثي الثانوي التكون الوحدات

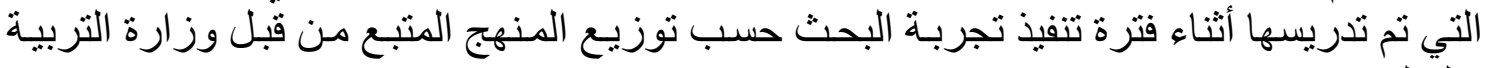
و التعليه. 
وقد قام الباحث بإعـادة صياغة محتوى الوحدات الثلاثة وفقا لنمـذذج أبعاد التعلم ثم قام

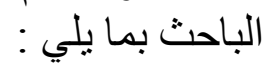

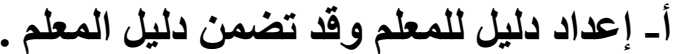

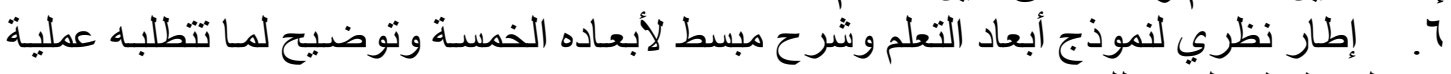

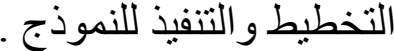
V. توجيهات و إرشـادات للمعلـم لمسـاعدته في تـدريس الوحدات الثلاثـة وفـق نمـوذج أبعـاد

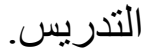
^. خطة زمنية بعدد الحصص اللازمة لتدريس موضو عات الوحدات الثلاثة وفقاً للنموذج .

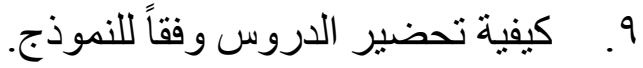
ب - إعداد كتيب للطالب :

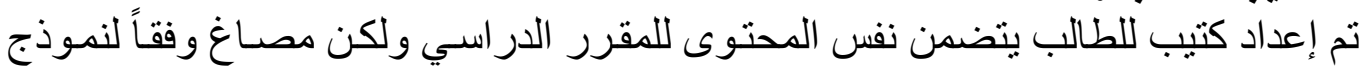

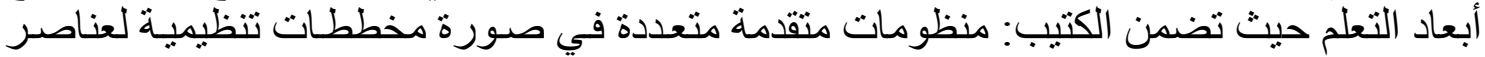

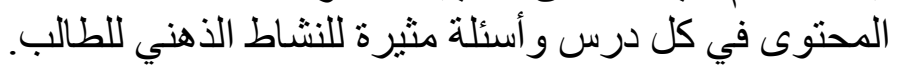

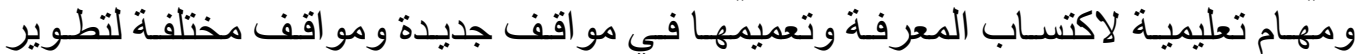

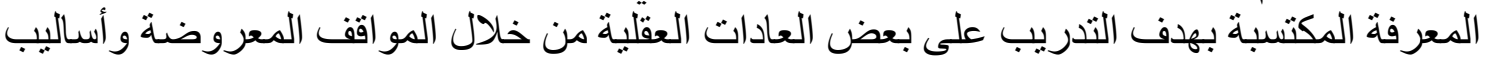

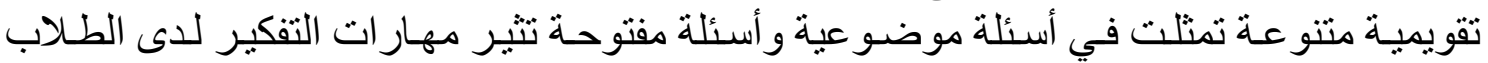

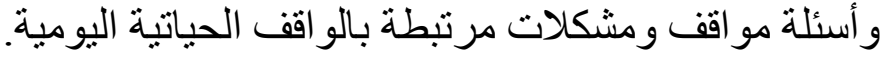

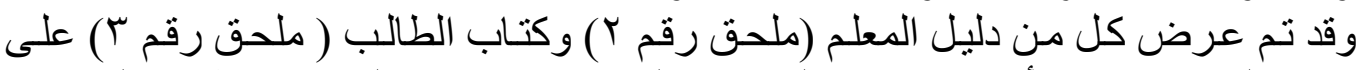

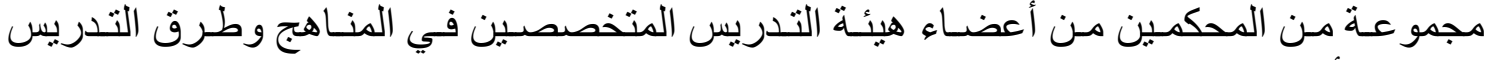

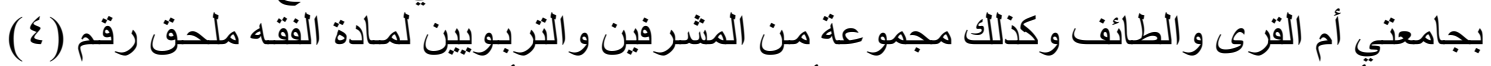

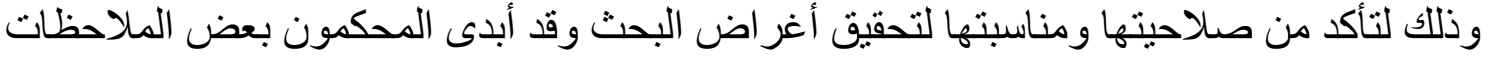

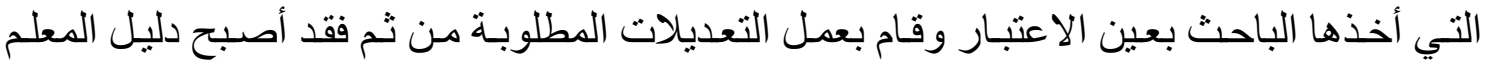
وكتيب الطالب صالحين للاستخدام.

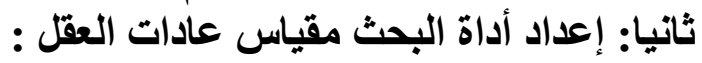

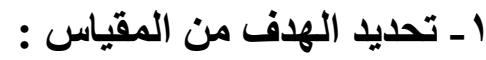

يهدف المقياس قياس ثماني عادات عقلية لدى طلاب الصفاس الصف الأول الثانوي بمدرسة الحوية

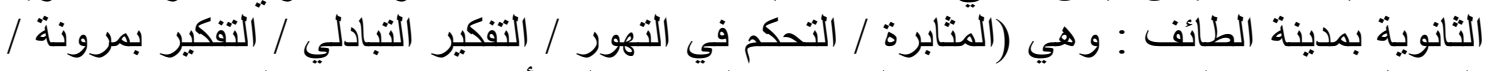

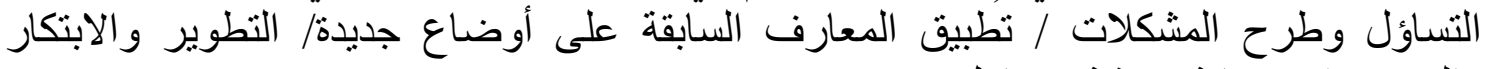
و التجديد/ الاستجابة بدهشة ولئة وتساؤل). وقد روعي أن تكون العادات العقلية المختارة منو افقة إلى حد كبير - مع النسب المحددة

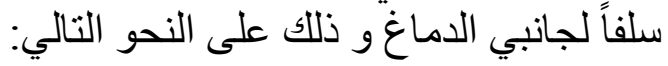

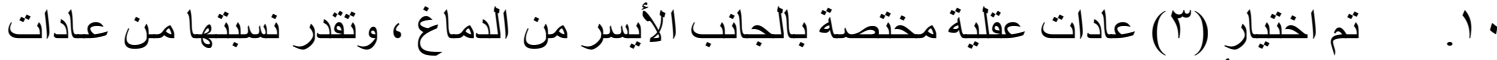

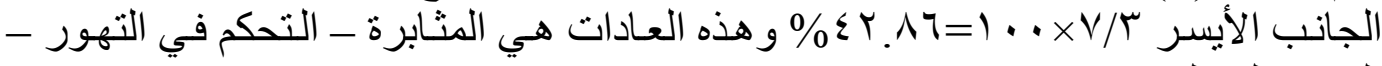
التفكير التبادلي الادبر تم اختيار (0) عادات عقلية مختصة بالجانب الأيمن من الدماغ واغ وتقدر نسبتها من عـادات

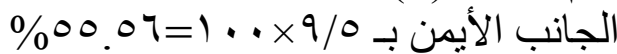

$$
\begin{aligned}
& \text { و هذه العادات هي : }
\end{aligned}
$$

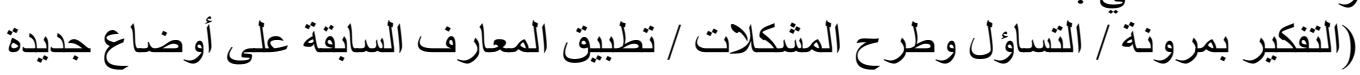


إعداد الصباغة الأولية لمفردات مقياس عادات العقل:

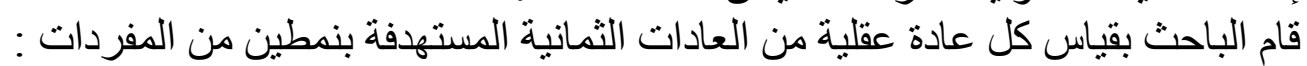

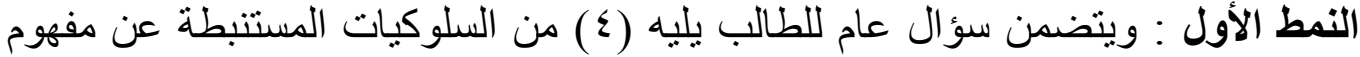

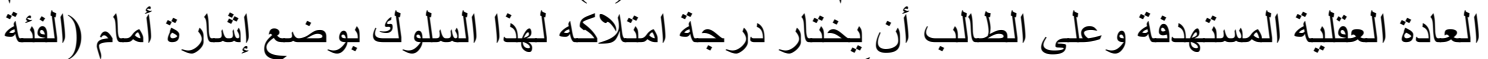
المعبر عن ذلك ) من وجهة نظره علماً بأن الدرجة المقدرة لكل فئة من فئات الاستجابة ممثلة

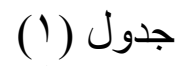

يوضح الدرجات المقدرة لفئة كل عبارة ايجابية أو سلبية

\begin{tabular}{|c|c|c|c|}
\hline \multicolumn{3}{|c|}{ فئات الاستجابة ودرجاتها المقرة } & \multirow{2}{*}{ 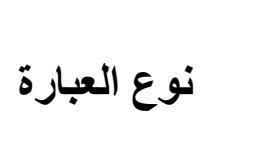 } \\
\hline 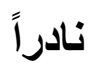 & أحياناً & دائماً & \\
\hline 1 & r & r & العبارة الايجابية \\
\hline$r$ & r & 1 & العبارة السلبية \\
\hline
\end{tabular}

النمط الثاني: ويتضمن إحدى الأنشطة المتنوعة :

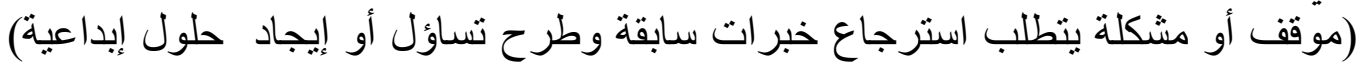

وكل نشاط من هذهالأنشطة يتطلب من الطالب استجابة معينة مرتبطة بسلوكيات العادة العقلية

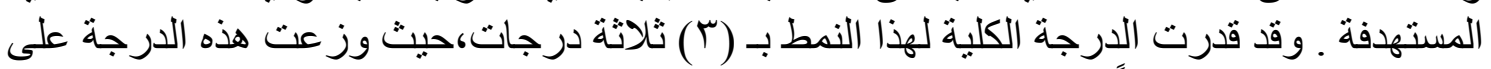

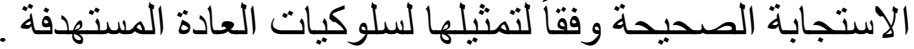

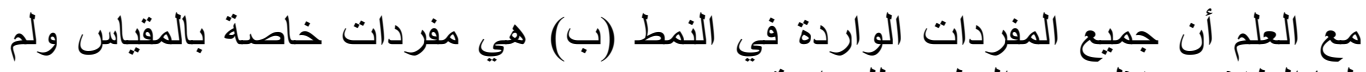

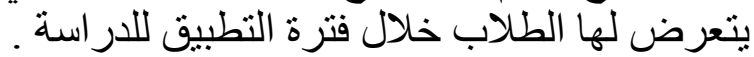
و الجدول التالي يوضح المو اصفات العامة لمقياس عادات العقل والوزن النسبي لكل عادة

$$
\text { جدول (Yo) }
$$

يوضح موصفات مقياس عادات العقل

\begin{tabular}{|c|c|c|c|c|c|c|}
\hline \multirow{2}{*}{ المئوية } & \multirow{2}{*}{ للالعظين } & \multicolumn{3}{|c|}{ عدد المفردات } & \multirow{2}{*}{ المستدة العقلّية } & \multirow{2}{*}{ نوع الدانب } \\
\hline & & (أ ،بطين & النمط (ب) & النمط (أ) & & \\
\hline$\% \backslash$ Y.o & 10 & 0 & 1 & $\varepsilon$ & المثابرة & \multirow{3}{*}{ الأجانبر } \\
\hline$\% \backslash$ Y.o & 10 & 0 & 1 & $\varepsilon$ & التحكم في التهور & \\
\hline$\%$ ) r.o & 10 & 0 & 1 & $\varepsilon$ & التفكير التبادلي & \\
\hline$\%)$ r.o & 10 & 0 & 1 & $\varepsilon$ & التفكير بمرونة & الأجانب \\
\hline
\end{tabular}




\begin{tabular}{|c|c|c|c|c|c|c|}
\hline$\% \backslash$ Y.o & 10 & 0 & 1 & $\varepsilon$ & التساؤل وطرح المشكلات & للاماغ \\
\hline$\% \backslash$ Y.o & 10 & 0 & 1 & $\varepsilon$ & تطبيق المعارف السابقة & \\
\hline$\% \backslash$ Y.o & 10 & 0 & 1 & $\varepsilon$ & التصور و التجديد والابتكار & \\
\hline$\% \backslash$ Y.o & 10 & 0 & 1 & $\varepsilon$ & الاستجابة بدهشة & \\
\hline$\% 1 \ldots$ & $1 \%$. & $\varepsilon$. & $\wedge$ & rr & المجموع & \\
\hline
\end{tabular}

r- تقرير درجات تصحيح مقياس عادات العقل :

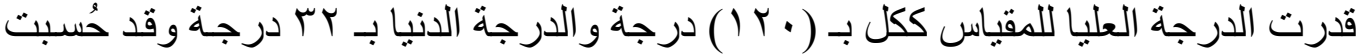

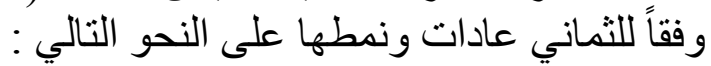
الارجة العليا للمقايس بنمطيه:

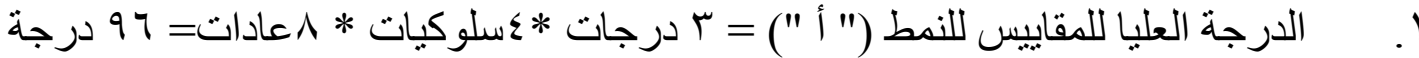

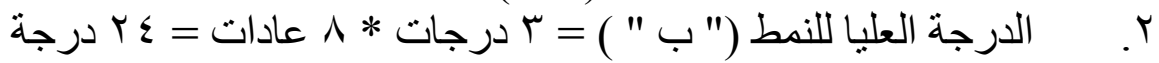
الارجة الانيا للمقياس بنمطية :

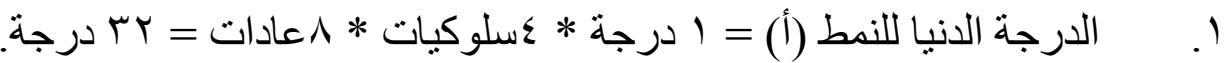

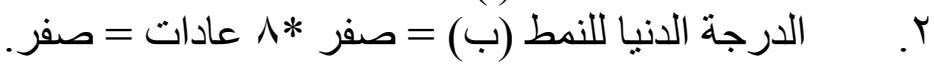

\section{ع ـ تحديد صدق مقياس عادات العقلّ :}

تم التحقق من صدق مقياس العقل من خلال عرضة علد على مجموعه من المحكمين

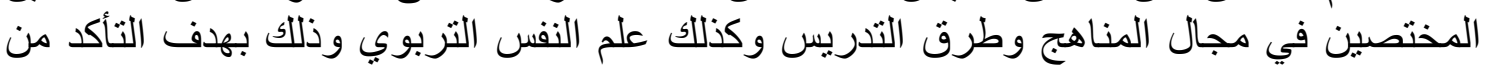

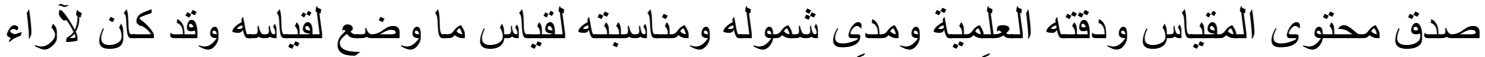

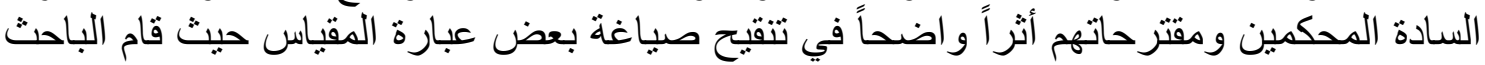

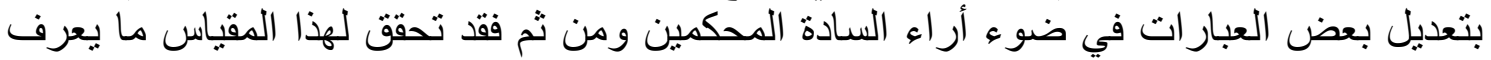

أما الصدق الداخلي أو التجانس الداخلي فقد تم حسابه بحساب معامل الارتباط بين درجة الته

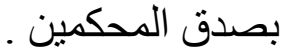

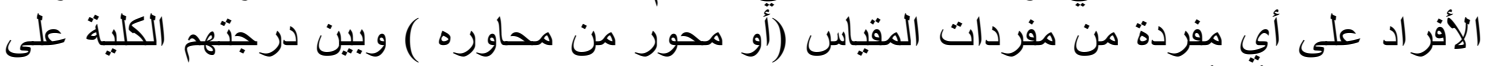

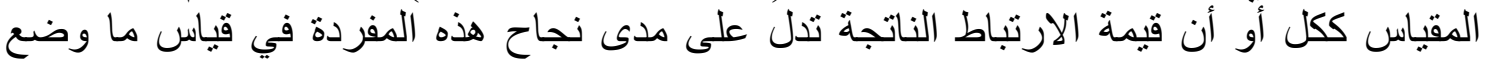

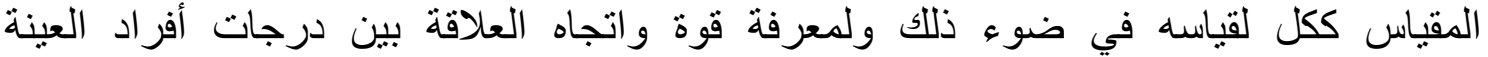
الاستطلاعية المكونة من (·) طالب على محاور مقياس عادات العقل وبين درجاتهم الكلية للمقياس باستخدام معامل ارتباط بيرسون المتوفر ضمن برن برنامج

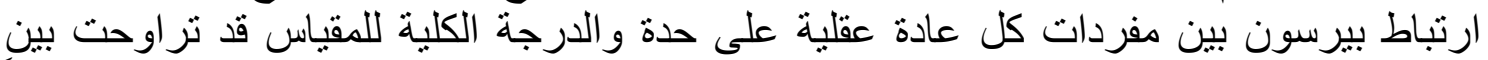

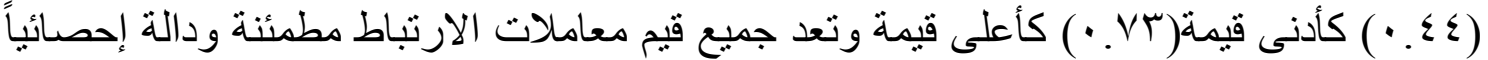

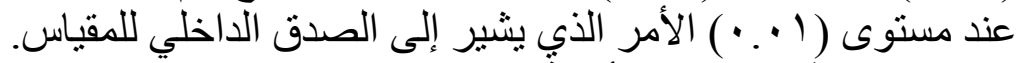

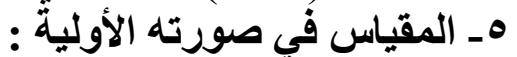

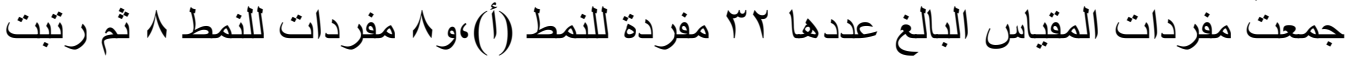
بحيث جاءت مفردات النمط (أ) متتالية للعادات العقلية الثمانية، ثم يليها مفرداداد ادات النمط (ب) وقد 


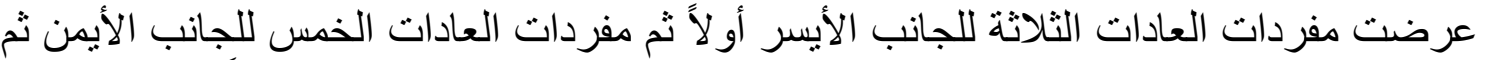

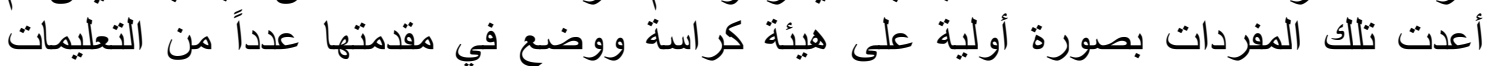

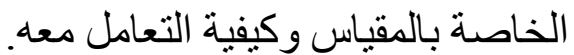

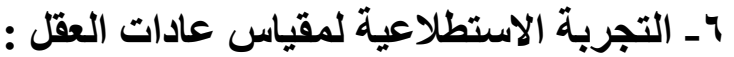
بعد إعداد المقياس في صورته الأولية ثم تطبيقه على عينة استطلاعية من ·r طالب من غير أفر اد عينة البحث. وكان الهدف من هذا التطبيق ما يلي :

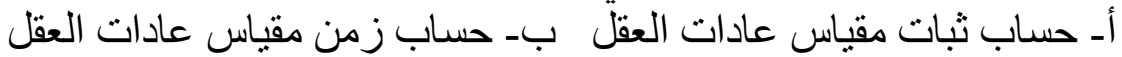

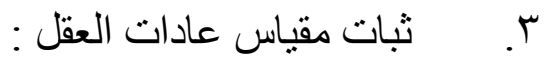

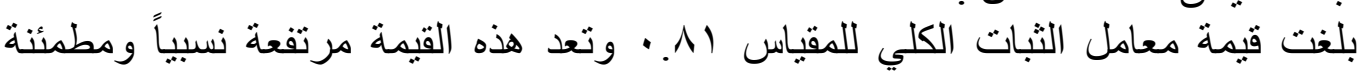

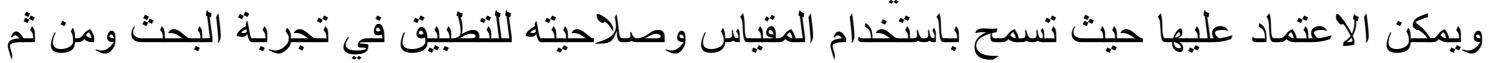

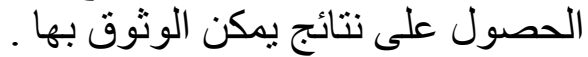

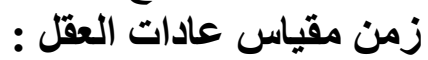
تم حساب الزمن من خلال تسجيل الذي استغرقه كل طالب في الإجابة عن المقياس وقد تم حساب الزمن عن طريق المعادلة التالية: الزمن المناسب = مجموع الأزمنة التي استغرقتها إجابة جميع الطلاب

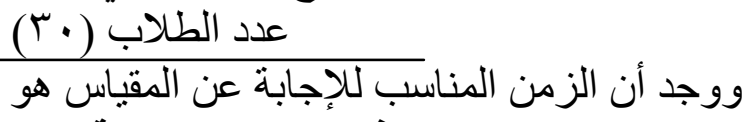

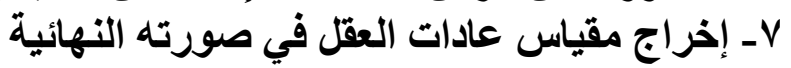

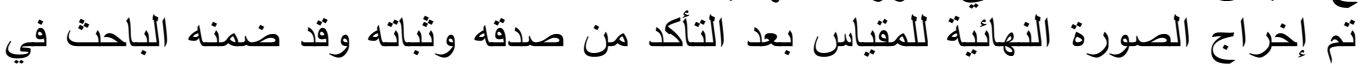

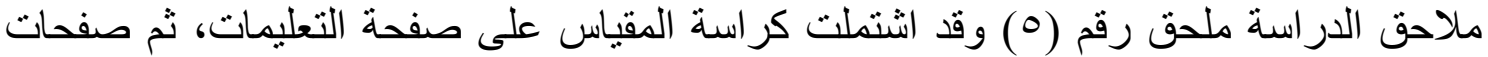

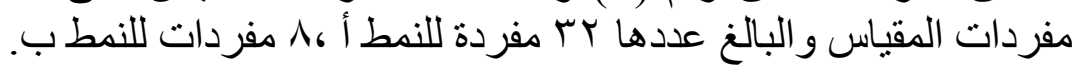
وبعد هذه الإجراءات أصبح المقياس في صورته اللهائ النهائية صالحا للتطبيق والاستخدام في

تجربة البحث .

ثالثا: التطبيق القبلي لمقياس عادات العقل:

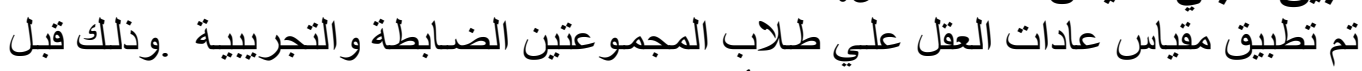

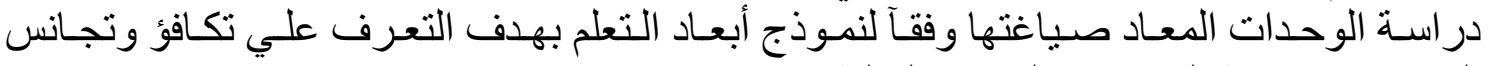
المجمو عنين عينة البحث في العادات العقاد العقلية. ولالإجابة على سؤ ال البحث:

لا توجد فرِوق دالة إحصائياً بين منوسط أداء المجمو عتين الضابطة و التجريبية في مقياس

$$
\text { جدول(r) جنئ) }
$$

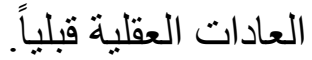

دلالة الفروق بين متوسطي درجات المجمو عتين (التجريبية ـ الضابطة)في التطبيق القبلي لقياس

\begin{tabular}{|c|c|c|c|c|c|c|}
\hline الدلالة & $ت$ & $\varepsilon$ & p & ن & مجموعة الارسة & العادات العقلية \\
\hline$\cdot . \leqslant 7$ &. .17 & 1.94 & $9 . \times 1$ & $\Gamma \varepsilon$ & ضابطة & 1 ـالمثابرة \\
\hline
\end{tabular}

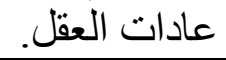




\begin{tabular}{|c|c|c|c|c|c|c|}
\hline غير دالة & & r. 9 & $9.7 \varepsilon$ & سTr & تجريبية & \\
\hline \multirow{2}{*}{ غير دالة } & \multirow{2}{*}{$\cdot r \Lambda$} & 1.9. & $9 . \cdot V$ & T乏 & ضابطة & \multirow{2}{*}{ ץ_التحكم من التهور } \\
\hline & & 1.00 & 9.11 & سד & تجريبية & \\
\hline \multirow{2}{*}{ غير دالة } & \multirow{2}{*}{.11} & Y.rร & $1 \cdot . r 4$ & Ts & ضابطة & \multirow{2}{*}{ r_التقليد التبادلي } \\
\hline & & $r . \varepsilon r$ & $1 . .50$ & r & تجريبية & \\
\hline \multirow{2}{*}{ غير دُّة } & \multirow{2}{*}{.11} & $1 . V \wedge$ & 9.0. & T纟 & ضابطة & \multirow{2}{*}{ ع ـ التفكير بمرونة } \\
\hline & & $1 . V$. & $9 . \leqslant 0$ & س & تجريبية & \\
\hline \multirow{2}{*}{ غير دالة } & \multirow{2}{*}{$.1 \mathrm{~V}$} & $1 . \wedge \varepsilon$. & $1 . .1 \leq$ & Tz & ضابطة & \multirow{2}{*}{ 0ـ التساؤل وطر ح } \\
\hline & & $r . T$ & $1 \cdot . v$ & Tr & تجريبية & \\
\hline .11 & \multirow{2}{*}{$\because 0$} & $r .9$ & 1.90 & T纟 & ضابطة & \multirow{2}{*}{ 7 ـ تطبيق المعارف } \\
\hline غير دالة & & r.ro & $\Lambda .9 \mu$ & r & تجريبية & \\
\hline$\because \wedge$ & \multirow{2}{*}{1.4} & $r . r$ & 9.00 & Tะ & ضابطة & \multirow{2}{*}{ 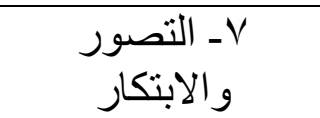 } \\
\hline غير دالة & & 1.07 & $9.1 \leq$ & r & تجريبية & \\
\hline \multirow{2}{*}{ غير دالة } & \multirow{2}{*}{ س } & $1.1 \mathrm{~V}$ & 11.74 & TE & ضابطة & \multirow{2}{*}{ ^ــ الاستجابة بدهشة } \\
\hline & & 1.09 & $11 . v \leqslant$ & سזr & تجريبية & \\
\hline \multirow{2}{*}{ غير دالة } & \multirow{2}{*}{ ש } & $1 \cdot . \leqslant V$ & $\vee \wedge .9$. & T & ضابطة & \multirow{2}{*}{ المقياس ككل } \\
\hline & & $1 . Y 7$ & Vᄉ. ไร & س & تجريبية & \\
\hline
\end{tabular}

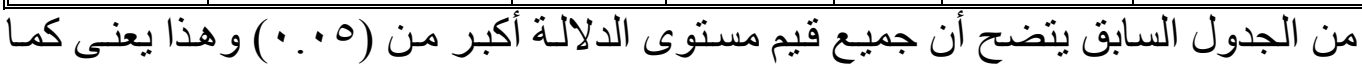

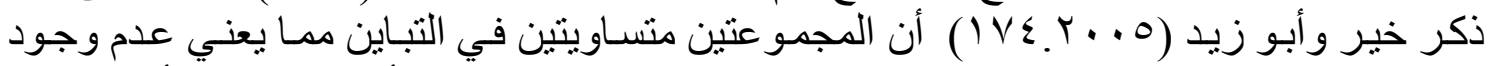

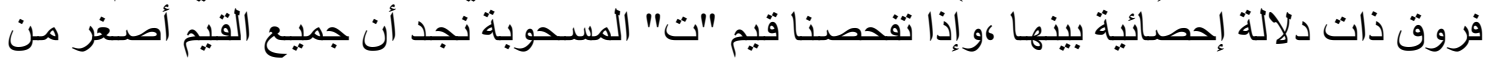

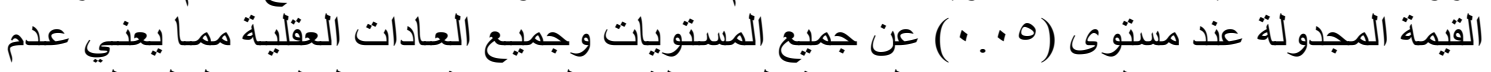

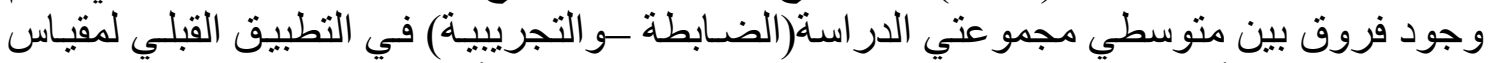

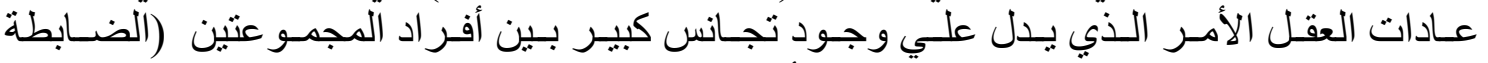

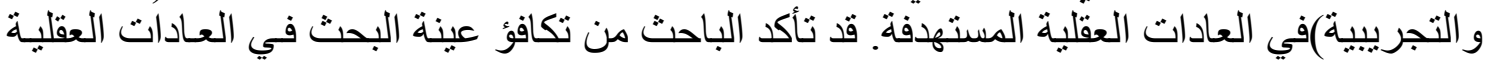

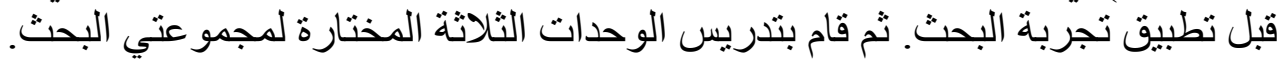

\section{نتائج البحث تفسير ها ومناقشتيها}

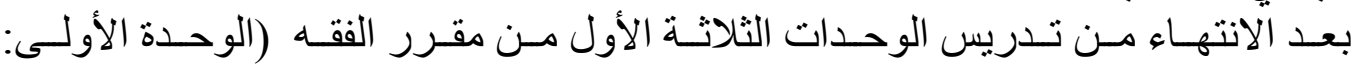
التطبيق البعدي لأداة البحث:

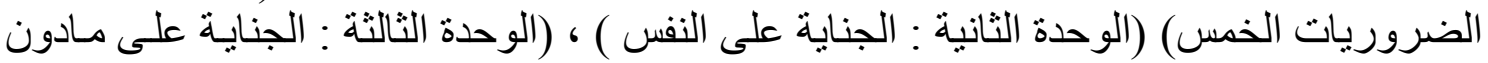

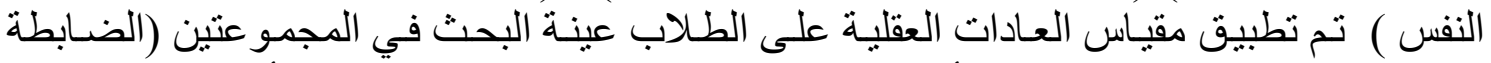

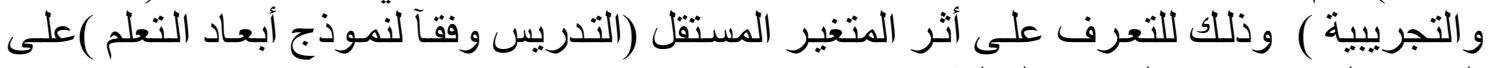

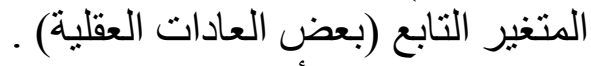

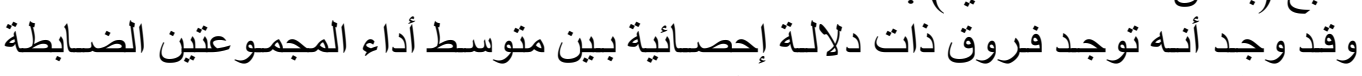

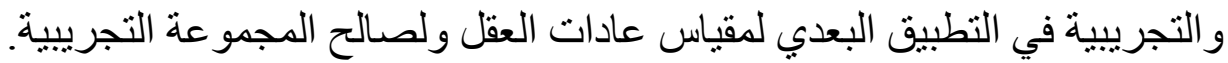

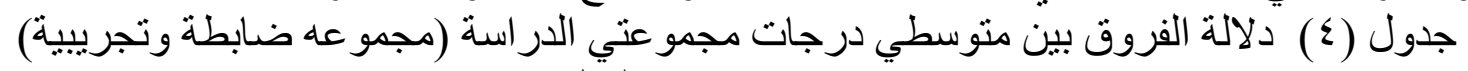

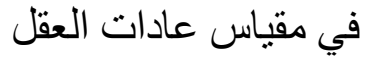




\begin{tabular}{|c|c|c|c|c|c|c|}
\hline الالالة & ت & $\varepsilon$ & r & $\dot{ن}$ & مجموعة الدراسة & العادات العقلية \\
\hline \multirow{2}{*}{ دال عند } & \multirow{2}{*}{0.71} & r.M & $1 \cdot . \Lambda$ & $r \varepsilon$ & ضابطة & \multirow{2}{*}{ ا ـالمثابرة } \\
\hline & & $1 . r 0$ & 14.00 & س & تجريبية & \\
\hline \multirow{2}{*}{ دال عند } & \multirow{2}{*}{ r.7) } & $r . . r$ & $9 . \vee \leqslant$ & $r \varepsilon$ & ضابطة & \multirow{2}{*}{ ץ_التحكم من التهور } \\
\hline & & 1.01 & $11.1 \mathrm{~V}$ & س & تجريبية & \\
\hline \multirow{2}{*}{ دال عند . . } & \multirow{2}{*}{$\varepsilon . v_{1}$} & T.YY & $1 \cdot .11$ & rs & ضابطة & \multirow{2}{*}{ rـالتقليد التبادلي } \\
\hline & & $1.0 \mathrm{~V}$ & Ir.Vq & Tr & تجريبية & \\
\hline \multirow{2}{*}{ دال عند } & \multirow{2}{*}{$\varepsilon .0 \leqslant$} & 1.71 & $1.0 \mathrm{~V}$ & TE & ضابطة & \multirow{2}{*}{ عـ التفكير بمرونة } \\
\hline & & $1 . T V$ & $1 r .0$ & س & تجريبية & \\
\hline \multirow{2}{*}{ دال عند } & \multirow{2}{*}{0.71} & $1 . V \varepsilon$ & $1 \cdot .11$ & rs & ضابطة & \multirow{2}{*}{ 0ـ التساؤل وطرح } \\
\hline & & I.r. & 14.79 & Tr & تجريبية & \\
\hline \multirow{2}{*}{ دال عند } & \multirow{2}{*}{7.1 . } & T.Mo & $V . \leqslant 7$ & $r \varepsilon$ & ضابطة & \multirow{2}{*}{ 7ـ تطبيق المعارف } \\
\hline & & T.YV & $1 \cdot \because r$ & 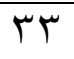 & تجريبية & \\
\hline \multirow{2}{*}{ دال عند } & \multirow{2}{*}{$\varepsilon .1 T$} & r.A & $1 \cdot \cdots$ & $\Gamma \varepsilon$ & ضابطة & \multirow{2}{*}{ و الابتكار } \\
\hline & & $1.1 \mathrm{~V}$ & $11.0 Y$ & Tr & تجريبية & \\
\hline \multirow{2}{*}{ دال عند } & \multirow{2}{*}{$\varepsilon .7$} & $1 . \wedge r$ & IT.T人 & $r \varepsilon$ & ضـابطة & \multirow{2}{*}{ يـ الاستجابة بدهشة } \\
\hline & & $1 . r$ & 17.79 & س & تجريبية & \\
\hline \multirow{2}{*}{ دال عند } & \multirow{2}{*}{ V. } & $11.1 \varepsilon$ & גז.ר & $r \varepsilon$ & ضابطة & \multirow{2}{*}{ المقياس ككل } \\
\hline & & 7.10 & $9 \wedge . \leqslant 1$ & س & تجريبية & \\
\hline
\end{tabular}

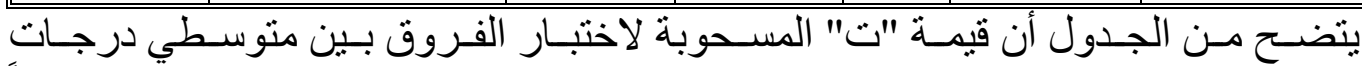

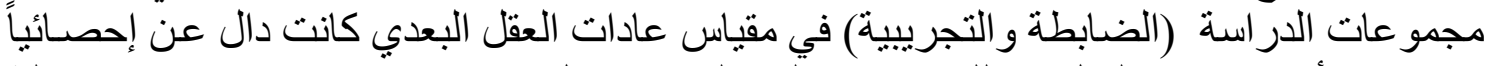

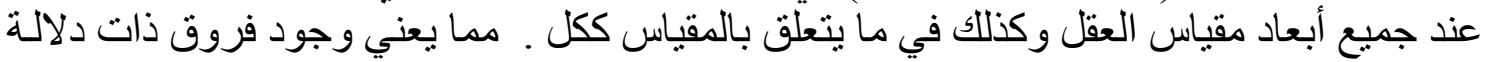

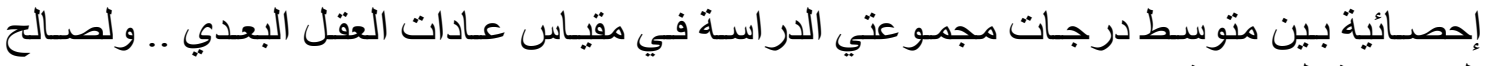

المجمو عة التجريبية. مناقشة النتائج :

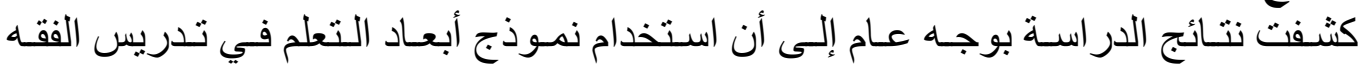

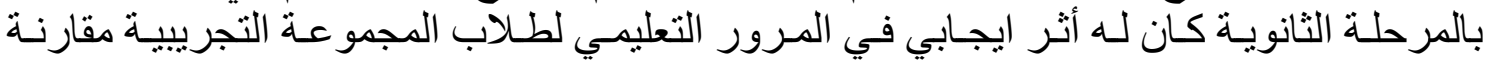

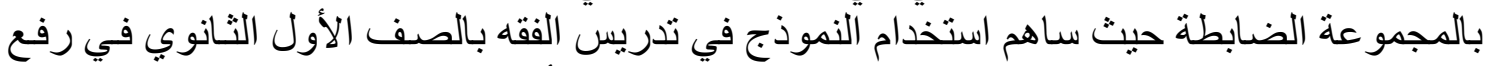

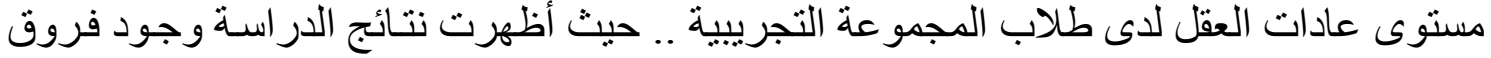

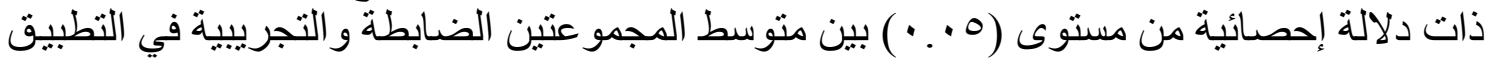

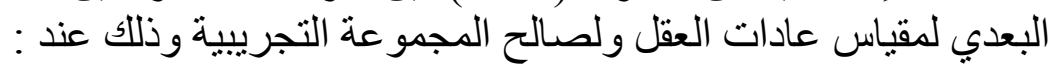

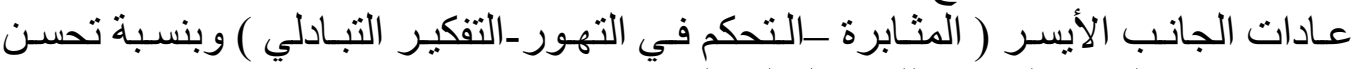




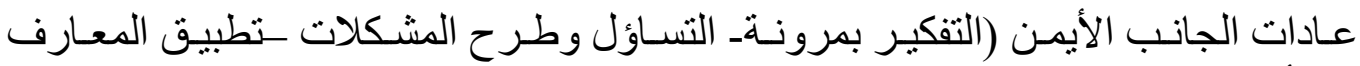

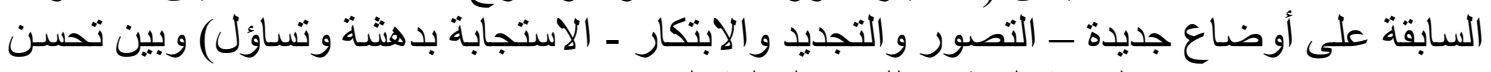

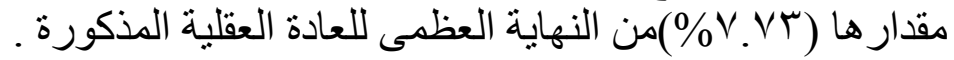

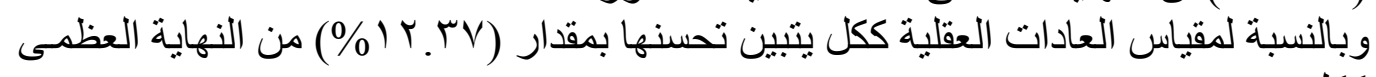

\section{وقد تعزى هذه النتائج إلى:} للمقياس ككل.

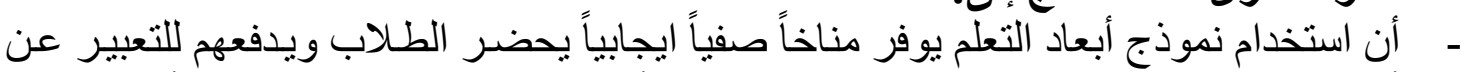

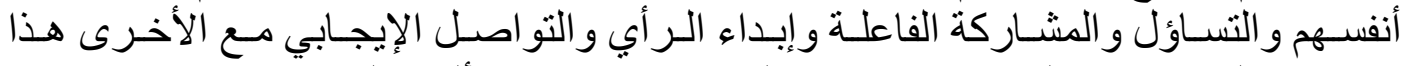

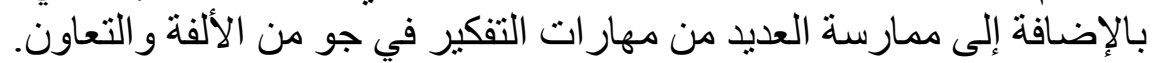

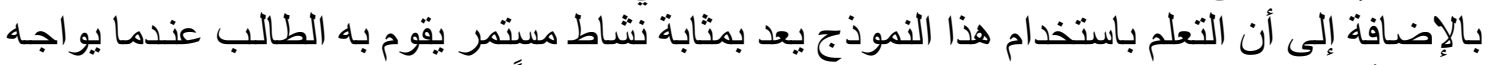

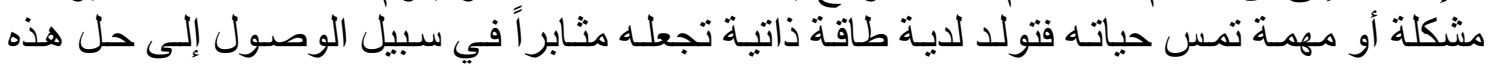

في ضوء ما أسفر عن البحث الحالي من نتائج فإنه بمكن تقديم التوصيات الآتية:

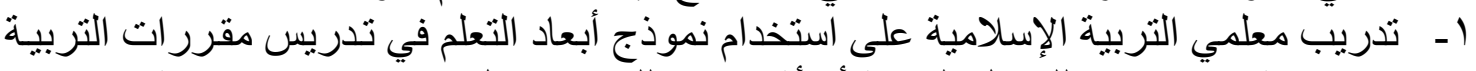

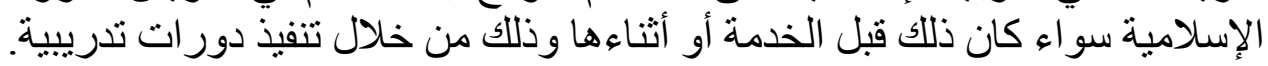

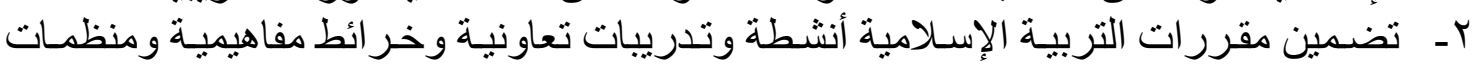

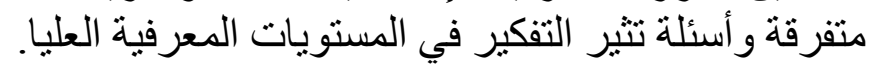

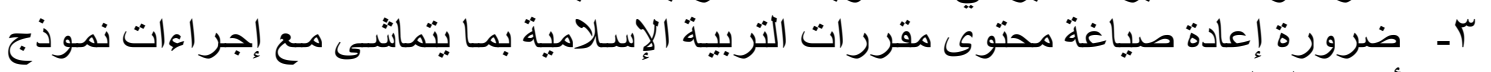
أبعاد التعلم ع - ت تطوير وتحديث العملية التعلمية بالمرحلة الثانوية بما يتمشى مع الاتجاهات العالمية المعاصرة

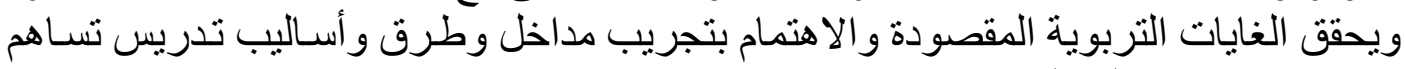
في تحقيق ايجابية المتعلم

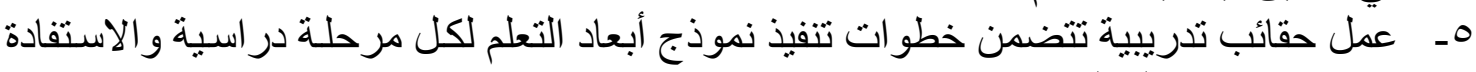
منها في تدريب المعلمين.

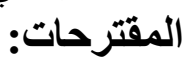
1 - در اسة أثر استخدام نموذج أبعاد التعلم على التحصيل في مقررات التربية الإسلامية المختلفة

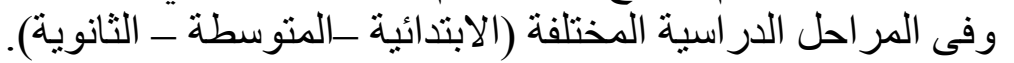

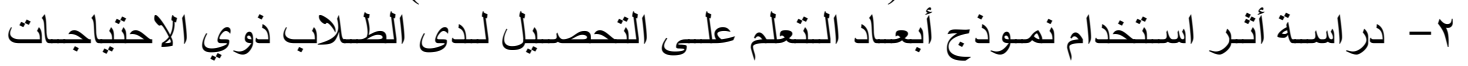
الخاصة.

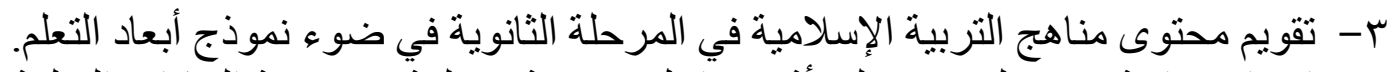

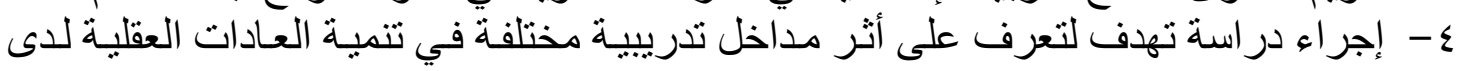

\section{المراجع} الطلاب المرحلة الثانوية.

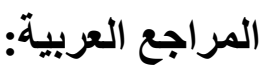

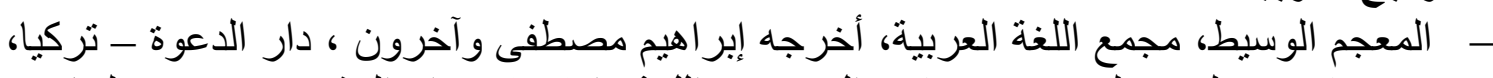

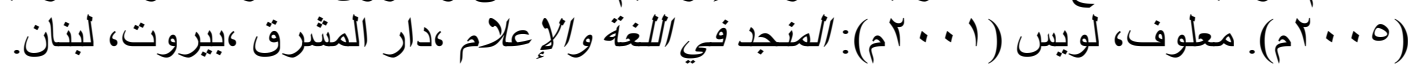

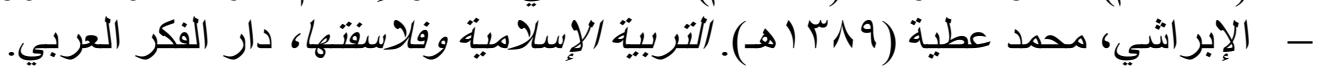




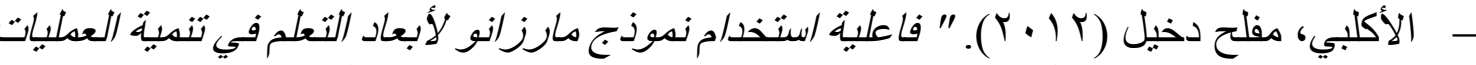

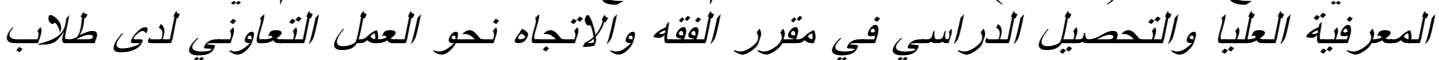

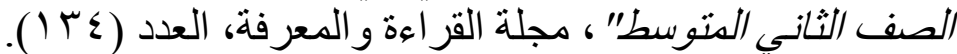

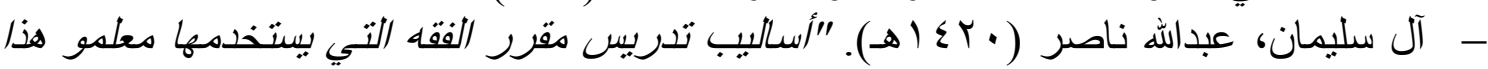

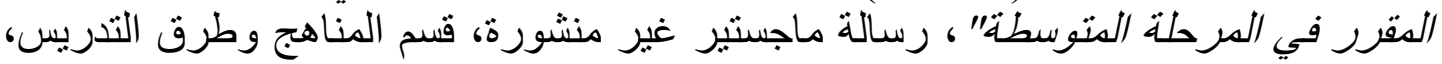

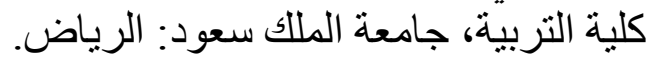

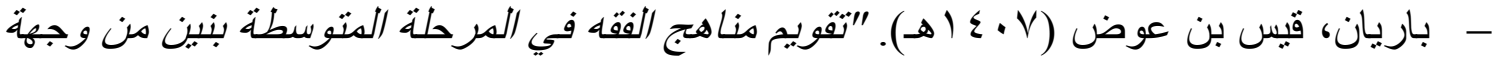

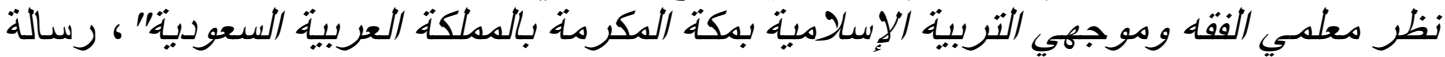
ماجستير غير منشورة، قسم المناهج وطرق التدريس، كلية التربية، جامعة أم القرى: مكة لئه المكرمة. ماجن.

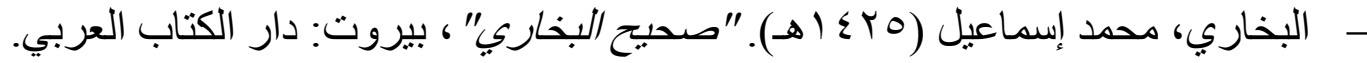

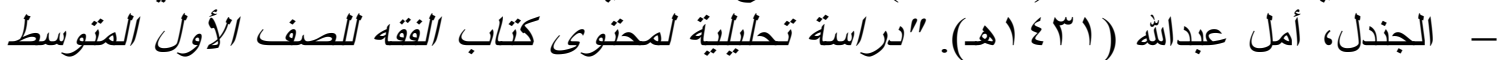

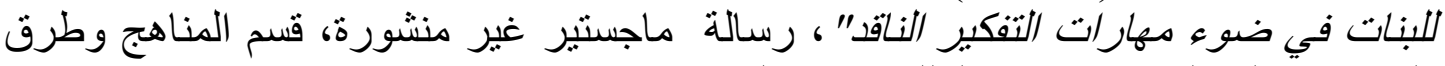

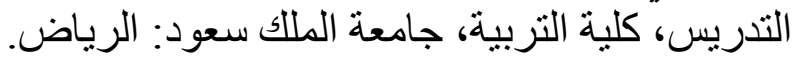

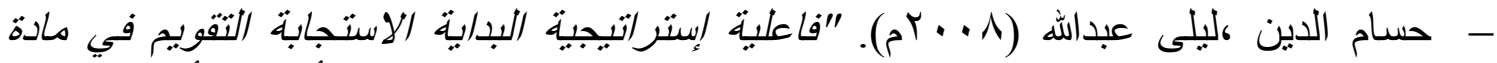

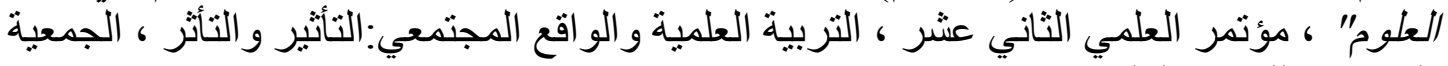

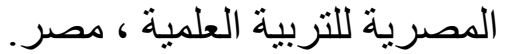

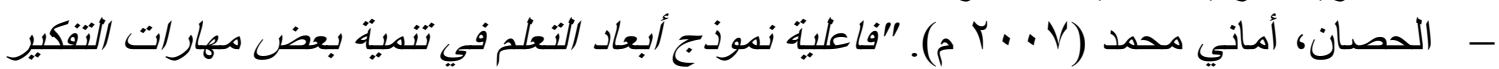

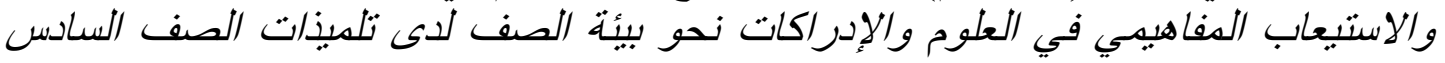

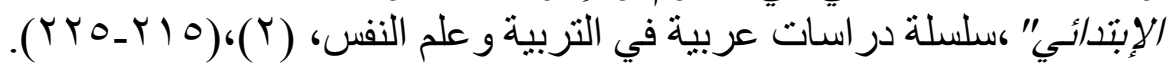

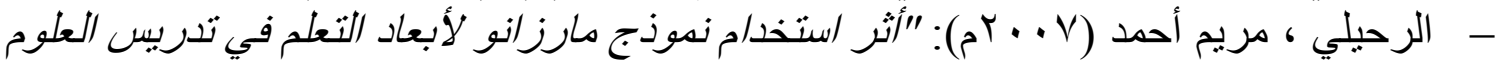

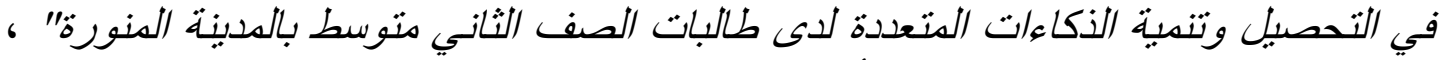

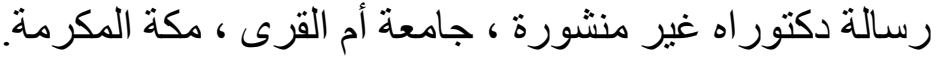

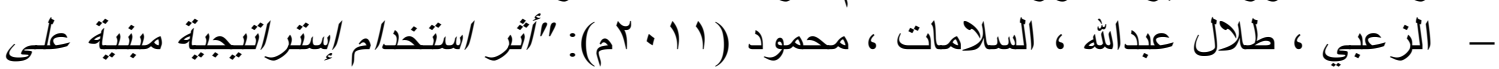

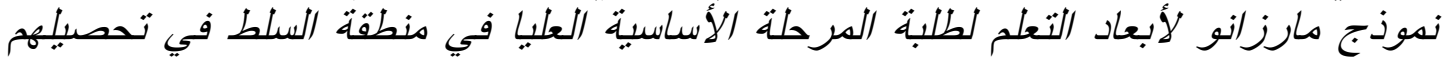

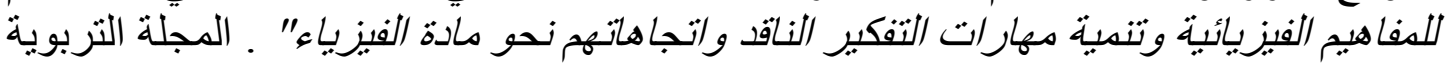
، مجلس النشر العلمي، جامعة الكويته

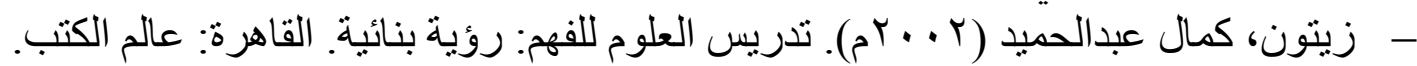

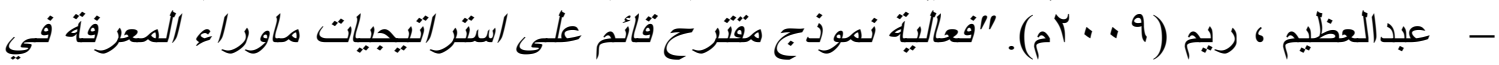

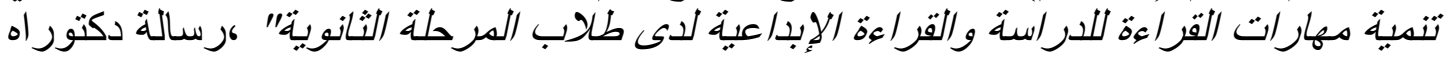

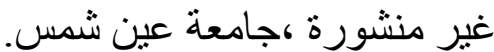

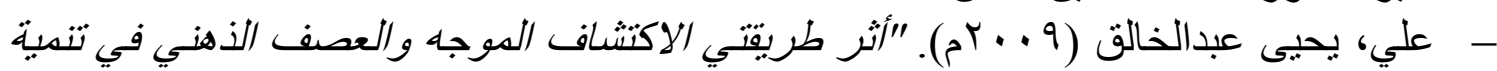

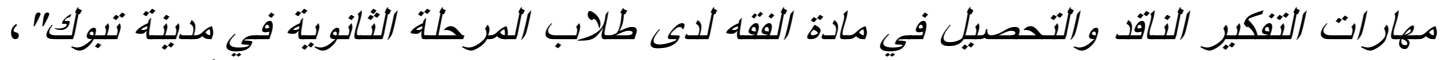

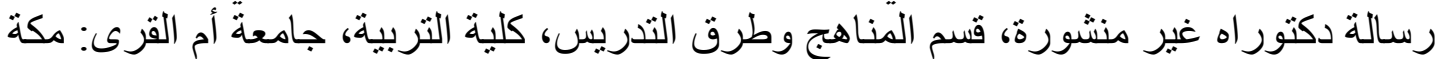
- الغامدي، أحمد محمد (·99 (م). "تنمية بعض كفاءات التندربس لدى معلم التربية الإسلامبية بالهرحلة الثانوية العامة في المملكة العربية السعودية"، رسالة دكتوراه غير منشورة، كلية التربية: جامعة عين شمس. 


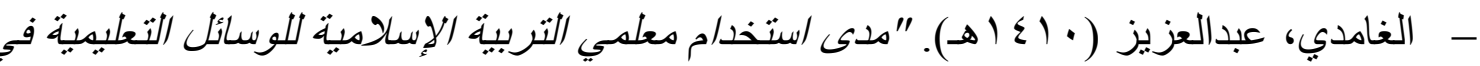

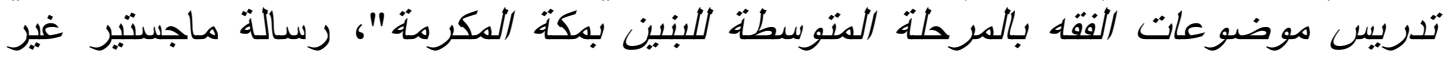

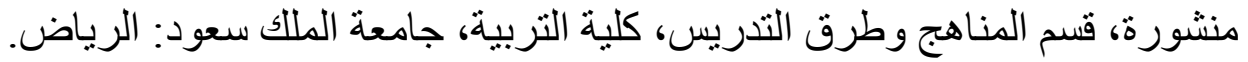

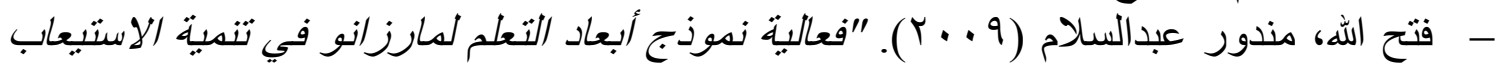

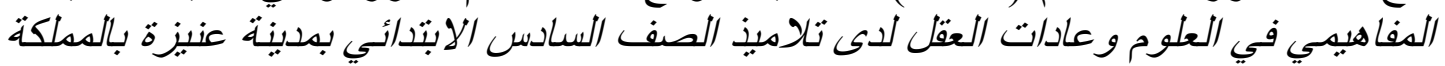

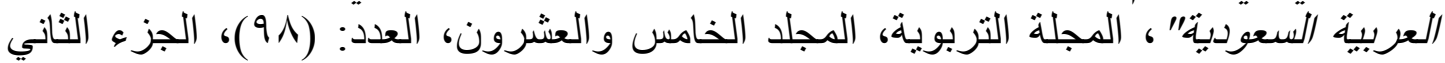

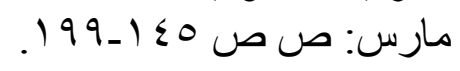

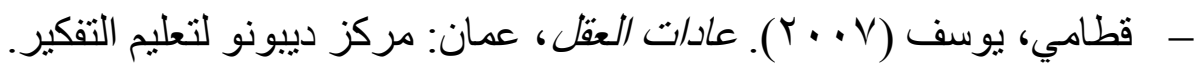

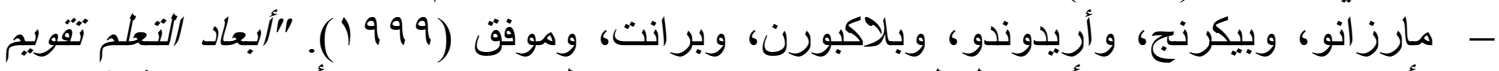

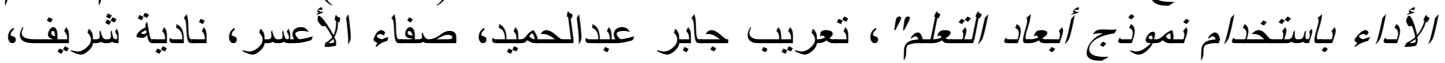

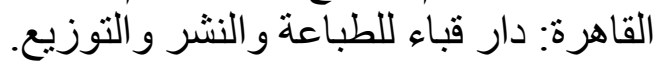

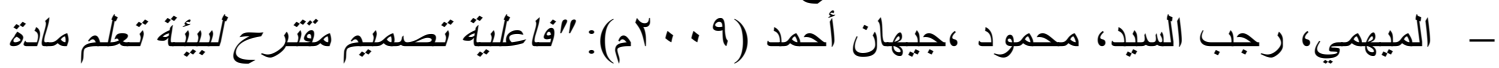

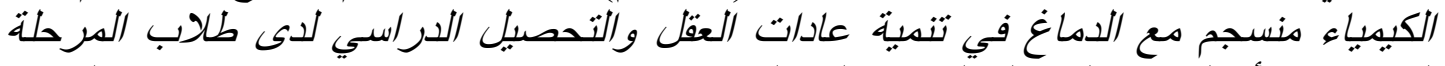

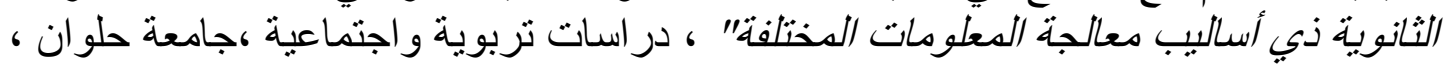
- النحلاوي، عبدالرحمن (بrأ (هـ). أصول التربية الإسلامية وأساليبها في البيت والددرسة

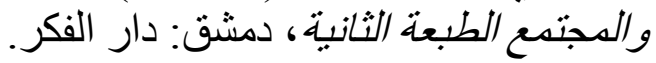

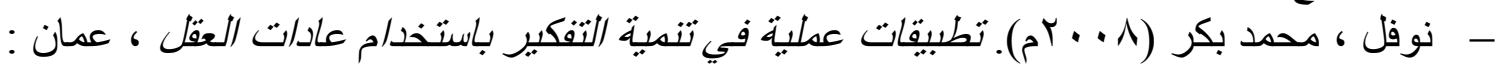

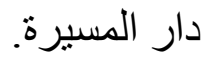

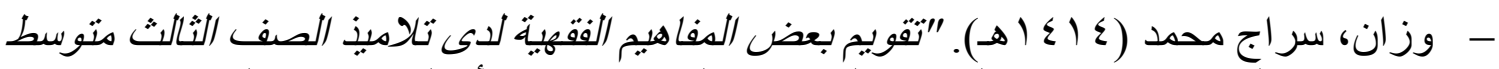
بدينة مكة المكرمة" ، مركز البحوث التربوية و النفسية، جامعة أم القرى: مكة المكرمة.

\section{المراجع الأجنبية}

- Costa, A \&Garmston, R (2001). Cognitive coaching: A foundation for Renaissance Schools. Norwood, Ma: Christopher Gordon Pubs.

- Marzano, R., (1997): "Dimensions of learning", Teacher Professional development", Available.

- Marzano, R., Pichering, D., Arredondo, D., Paynter, D. Blackburn, G., Brandt, R. Moffet, S. \& Pollock, J. (1997): Dimensions of learning Teacher's Manual, 2nd ed, Aurora, Colorado: MCREL.

- Marzano, R. (1998): "Models of standards implementation: implications for the classroom", Eric Database (ED427088).

- Marzano R. (1993): "How Classroom Teacher Approach the Dimensions of Thinking" Theory Into Practice, Vol. 32, 3, pp: 154-160.

- Marzano R. et al. (1990) (a): Dimensions of Learning - An Integrative Instructional Framework, U. S, Virginia, Alexandria, Association for Supervision and Curriculum Development. 